\title{
Extended Spectrum Beta-Lactamase Escherichia coli in River Waters Collected from Two Cities in Ghana, 2018-2020
}

\author{
Regina Ama Banu 1,*, Jorge Matheu Alvarez ${ }^{2}$, Anthony J. Reid ${ }^{3}$, Wendemagegn Enbiale 4,5 (D), \\ Appiah-Korang Labi ${ }^{6}$, Ebenezer D. O. Ansa ${ }^{7}$, Edith Andrews Annan ${ }^{8}$, Mark Osa Akrong ${ }^{1}$, Selorm Borbor ${ }^{1}$, \\ Lady A. B. Adomako ${ }^{1}$ (D) Hawa Ahmed ${ }^{1}$ (D), Mohammed Bello Mustapha ${ }^{1}$, Hayk Davtyan ${ }^{9}$ (D), Phillip Owiti ${ }^{10}$, \\ George Kwesi Hedidor ${ }^{6}$, Gerard Quarcoo ${ }^{1}$ (D), David Opare ${ }^{11}$, Boi Kikimoto ${ }^{12}$, Mike Y. Osei-Atweneboana ${ }^{1}$ (D) \\ and Heike Schmitt ${ }^{13,14}$
}

check for updates

Citation: Banu, R.A.; Alvarez, J.M.; Reid, A.J.; Enbiale, W.; Labi, A.-K.; Ansa, E.D.O.; Annan, E.A.; Akrong, M.O.; Borbor, S.; Adomako, L.A.B.; et al. Extended Spectrum Beta-Lactamase Escherichia coli in River Waters Collected from Two Cities in Ghana, 2018-2020. Trop. Med. Infect. Dis. 2021, 6, 105. https:// doi.org/10.3390/tropicalmed6020105

Academic Editors: Olga Perovic,

Tom Decroo and Chakaya

Muhwa Jeremiah

Received: 2 June 2021

Accepted: 15 June 2021

Published: 20 June 2021

Publisher's Note: MDPI stays neutral with regard to jurisdictional claims in published maps and institutional affiliations.

Copyright: (c) 2021 by the authors. Licensee MDPI, Basel, Switzerland. This article is an open access article distributed under the terms and conditions of the Creative Commons Attribution (CC BY) license (https:// creativecommons.org/licenses/by/ $4.0 /)$.
1 CSIR-Water Research Institute, Council for Scientific and Industrial Research, 2nd CSIR Close, Achimota, Accra P.O. Box AH 38, Ghana; markosaakrong@gmail.com (M.O.A.); borborviich.sb@gmail.com (S.B.); asantewa84@gmail.com (L.A.B.A.); hawaahmed360@yahoo.com (H.A.); yarbello@yahoo.com (M.B.M.); gquarcoo@csir-water.com (G.Q.); oseiatweneboana@yahoo.co.uk (M.Y.O.-A.)

2 Department of Surveillance Prevention and Control of AMR, AMR Division, World Health Organization, Route de Sauverny 22, 1290 Versoix, Switzerland; matheujo@who.int

3 Operational Research Unit (LuxOR), Medical Department, Médecins Sans Frontières Operational Centre Brussels, L-1617 Luxembourg, Luxembourg; tony.reid@brussels.msf.org

4 Dermatovenereology Department, Bahir Dar University, BahirDar P.O. Box 1996, Ethiopia; wendemagegnenbiale@gmail.com

5 Amsterdam UMC, Academic Medical Centre, Department of Dermatology, Amsterdam Institute for Infection and Immunity (AI\&I), University of Amsterdam, 1012 WX Amsterdam, The Netherlands

6 WHO Country Office, Ghana, 7 Ameda Street, Roman Ridge, Accra P.O. Box MB 142, Ghana; labia@who.int (A.-K.L.); hedidorg@who.int (G.K.H.)

7 Council for Scientific and Industrial Research-Animal Research Institute, Adenta-Frafraha, Achimota-Accra P.O. Box AH 20, Ghana; edoansa@yahoo.com

8 World Health Organization, Harare, Zimbabwe; andrewse@who.int

9 Tuberculosis Research and Prevention Center NGO, Yerevan 0040, Armenia; haykdav@gmail.com

10 The International Union against Tuberculosis and Lung Disease, 68 Boulevard Saint Michel, 75006 Paris, France; philip.owiti@theunion.org

11 National Public Health \& Reference Laboratory Ghana Health Service, Accra P.O. Box 300, Ghana; opared_60@yahoo.co.uk

12 National Food Safety/AMR Reference Laboratory for Animal Health (Terrestrial \& Aquatic Animals), Veterinary Services, Accra P.O. Box M 161, Ghana; boikikimoto@gmail.com

13 Centre for Zoonoses and Environmental Microbiology, Centre for Infectious Disease Control, National Institute for Public Health and the Environment (RIVM), P.O. Box 1, 3720 BA Bilthoven, The Netherlands; heike.schmitt@rivm.nl

14 WHO Collaborating Centre for Risk Assessment of Pathogens in Food and Water at the National Institute for Public Health and the Environment (RIVM), P.O. Box 1, 3720 BA Bilthoven, The Netherlands

* Correspondence: reginaamabanu@csir-water.com; Tel.: +233-243212783

Abstract: Infections by Extended-Spectrum Beta-Lactamase producing Escherichia coli (ESBL-Ec) are on the increase in Ghana, but the level of environmental contamination with this organism, which may contribute to growing Antimicrobial Resistance (AMR), is unknown. Using the WHO OneHealth Tricycle Protocol, we investigated the contamination of E. coli (Ec) and ESBL-Ec in two rivers in Ghana (Odaw in Accra and Okurudu in Kasoa) that receive effluents from human and animal wastewater hotspots over a 12-month period. Concentrations of Ec, ESBL-Ec and percent ESBL-Ec/Ec were determined per $100 \mathrm{~mL}$ sample. Of 96 samples, 94 (98\%) were positive for ESBL-Ec. concentrations per $100 \mathrm{~mL}(\mathrm{MCs} 100)$ of ESBL-Ec and \%ESBL-Ec from both rivers were $4.2 \times 10^{4}$ $\left(\mathrm{IQR}, 3.1 \times 10^{3}-2.3 \times 10^{5}\right)$ and 2.79 (IQR, 0.96-6.03), respectively. MCs100 were significantly lower in upstream waters: $1.8 \times 10^{4}\left(\mathrm{IQR}, 9.0 \times 10^{3}-3.9 \times 10^{4}\right)$ as compared to downstream waters: $1.9 \times 10^{6}$ $\left(\mathrm{IQR}, 3.7 \times 10^{5}-5.4 \times 10^{6}\right)$. Both human and animal wastewater effluents contributed to the increased contamination downstream. This study revealed high levels of ESBL-Ec in rivers flowing through two cities in Ghana. There is a need to manage the sources of contamination as they may contribute to the acquisition and spread of ESBL-Ec in humans and animals, thereby contributing to AMR. 
Keywords: ESBL-E. coli; environment; antimicrobial resistance; rivers; Ghana; tricycle protocol; operational research; sort it

\section{Introduction}

The rising problem of Antimicrobial Resistance (AMR) is well recognised as a major public health threat $[1,2]$. The health and economic consequences of AMR are severe, particularly in low and middle-income countries (LMICs) [3,4]. The increase in AMR is widely attributed to inappropriate use of antimicrobials in humans and animal husbandry $[5,6]$ with a resulting impact on the environment, which may, in turn, be a source for the acquisition and transfer of resistant genes.

Available studies on AMR and the environment are predominantly from high resource settings [7-9], with a gap in knowledge from low and middle-income settings [10,11]. AMR is facilitated by the discharge of poorly treated human and animal waste as well as antimicrobials from pharmaceutical industries and health facilities into the environment $[12,13]$. Antimicrobial-resistant organisms in the environment may then be transmitted to humans through the water supply and food chain [4]. The health of people connects to the health of the environment and AMR data from the environment will be useful in addressing the AMR problem in Ghana.

Extended-spectrum beta-lactamase (ESBL) producing organisms are resistant to important $\beta$-lactam antibiotics, which are broad-spectrum antimicrobials commonly used to manage infections $[4,12]$. They are also most often resistant to other classes of antibiotics thus leaving fewer treatment options when infections occur $[10,14]$.

In Ghana, various studies have shown that the burden of ESBL infections is on the increase, along with community carriage [15-17]. Although there is evidence to show that environmental sources may serve as a potential source of transmission of ESBL producing organisms [18-20], there are currently no studies on the presence of ESBL-producing organisms in water sources in Ghana. In a broader context, data on presence of ESBLproducing entero-bacteriaceae from the whole continent of Africa are extremely scarce. The few existing studies have shown the presence of ESBL-producing entero-bacteriaceae in sachet drinking water and wastewater (the Democratic Republic of Congo), in untreated wastewater, contaminated surface and groundwater [21], and in poultry and poultry environments [22] (Nigeria), highlighting that prevention of ESBL transmission through drinking water and surface water requires attention. This is because surface water in African urban environments, with open drains, is highly contaminated with faecal organisms [23].

Escherichia coli (E. coli) is used as an indicator of faecal contamination of water bodies when analyzing water [24]. The presence of Extended Spectrum Beta-Lactamase E. coli (ESBL-Ec) could then be also considered as an indicator for antimicrobial resistance in water sources $[25,26]$.

In AMR surveillance studies, the spotlight has remained on humans and animals perhaps due to the difficulties in enumerating pathogens from the environment, use of insufficiently sensitive analytical methods [27] or a lack of sufficient awareness of the environment's role in the transfer of resistance genes. Quantification of variables such as concentration of ESBL-E. coli (ESBL-Ec) and proportions of ESBL-Ec among E. coli from various water types, for instance, could provide baseline data for future comparison. The World Health Organizations' Tricycle Protocol for surveillance of ESBL-Ec in the environment demonstrates the use of these variables in various water types [28]. This protocol has been piloted and found useful in LMICs (Pakistan, Jordan, Indonesia, Nepal, India, Malaysia and Madagascar) [25,29], including Ghana. In these piloting countries, goals were to establish feasibility of the protocol and demonstrate increased inter-institutional collaboration upon implementation of the protocol. 
This study aimed to systematically gather information on the extent and origin of environmental contamination of surface water by ESBL-Ec. Specifically, this was achieved through applying the WHO Tricycle protocol for determining counts of E. coli and ESBL-Ec in upstream and downstream water of two river bodies, contaminated with animal and human wastewater located in Kasoa and Accra, Southern Ghana, for twelve months. We interpret the findings with respect to the feasibility of the WHO Tricycle protocol and with respect to the degree of environmental contamination.

\section{Materials and Methods}

2.1. Study Design

This is a cross-sectional, descriptive study using data from the pilot study of the Tricycle Protocol in Ghana from 2018 to 2020.

\subsection{Study Setting}

\subsubsection{General Setting}

Ghana is located in West Africa (see Figure 1) with a population of about 30 million [30]. The study site falls within the Coastal River Basin with an average annual rainfall of $800 \mathrm{~mm}$. It is the most urbanised basin in the country and is frequently contaminated by discharge from untreated waste sources and leachates from agrochemicals [31].

\subsubsection{Specific Setting: Accra and Its Sampling Locations}

Accra is the capital city of Ghana and is located in the south on the Atlantic coast. It has an estimated population of 2.5 million [32] with a sewage management plan that covers approximately $30 \%$ of the sewage generated. Accra has four sewage treatment plants, with approximately $15 \%$ of the total land area of Accra's central business district connected to a sewer network [33]. Seven percent of urban dwellers resort to open defecation [34,35]. Household sanitation coverage is approximately $28 \%$, with $72 \%$ of households using shared sanitation facilities [35].

The Odaw River is a major river that courses through Accra. It takes its source from the Akwapim Mountain range, runs through Kwabenya, a suburb of Accra, and a centralised open drain in Avenor. It finally empties into Korle lagoon, an outlet into the Atlantic Ocean.

Avenor, a popular catchment area around the Odaw River, is a light industrial area and has a major transport terminal linking Accra to many parts of the country. Surrounding these terminals are shopping centres and an open market characterised by heavy human activity. There are slums in this area known for their open defecation practices along the river. Upstream water samples from the Odaw River were taken from Kwabenya, located $23 \mathrm{~km}$ to the north of Avenor, where downstream samples were collected. Human wastewater was collected from a runoff point into the Odaw River whilst animal wastewater samples were taken from a drain outlet from a major slaughter slab (that deals in cattle, sheep and goats). The sampling points are shown on the map in Figure 1. 

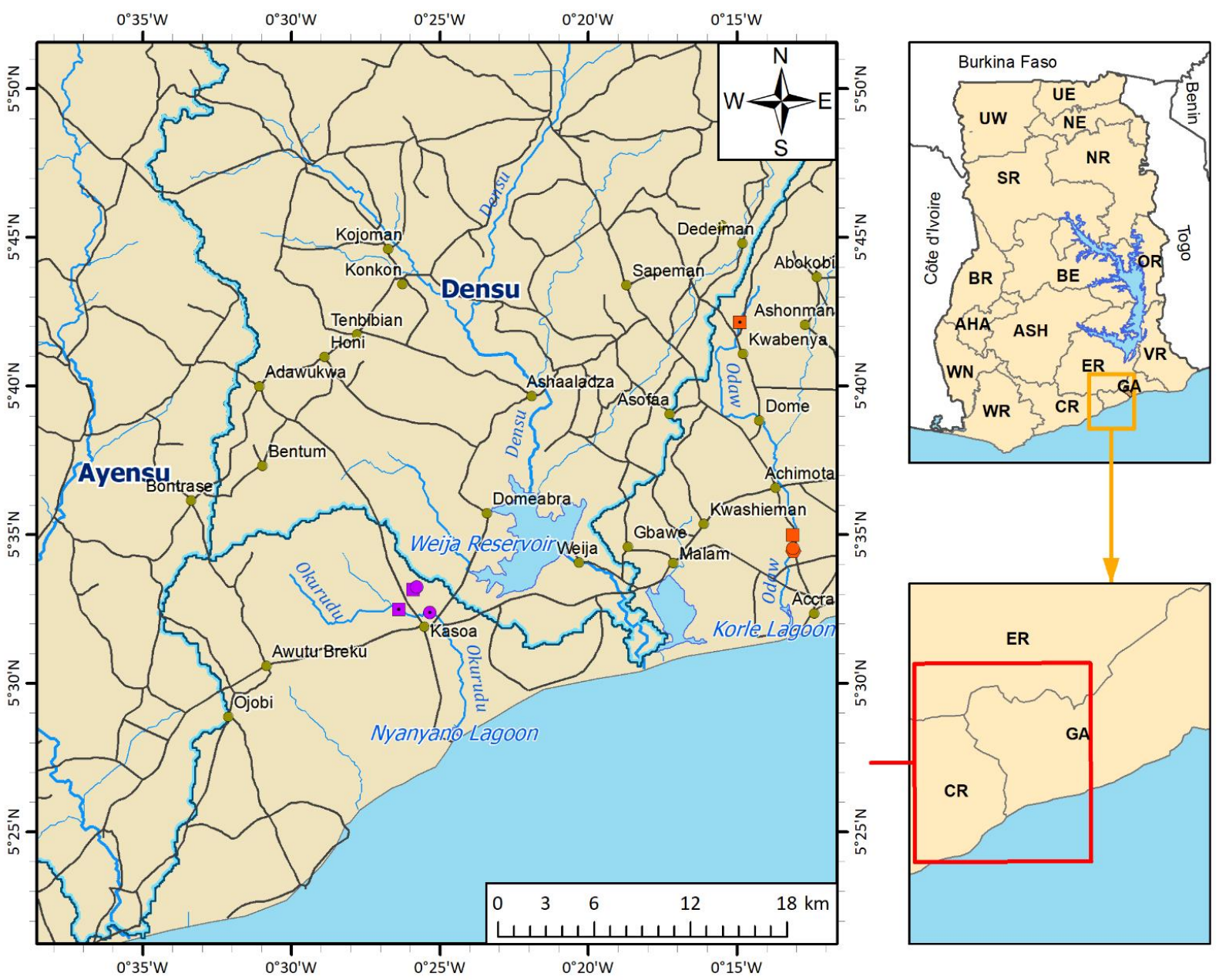

\begin{tabular}{|c|c|c|}
\hline Legend & & \\
\hline - Towns & Sampling Poir & \\
\hline $\begin{array}{l}\approx \text { Roads } \\
\sum \text { Wiver Basins } \\
\text { Waterbodies }\end{array}$ & $\begin{array}{l}\text { Accra } \\
\text { Animal Waste } \\
\text { Human Waste } \\
\text { Downstream } \\
\text { - Upstream }\end{array}$ & $\begin{array}{l}\text { Kasoa } \\
\text { - Animal Waste } \\
\text { - Human Waste } \\
\text { - Downstream } \\
\text { - Upstream }\end{array}$ \\
\hline
\end{tabular}

Figure 1. Map showing sampling points from Accra and Kasoa, for the periods of August 2018-December 2019, October 2019-February 2020, May and June 2020.

\subsubsection{Specific Setting: Kasoa and Its Sampling Locations}

Kasoa is a fast-growing peri-urban township in the Central Region of Ghana with a projected population of over 100,000. It is located further west, away from Accra. The master plan of Accra demarcated Kasoa to remain part of its green belt [36]. As a result, it did not have an original township development plan and has no centralised means of managing its waste. The community mostly uses shared public and household toilets. Kasoa discharges about $14 \%$ ( $246 \mathrm{~m}^{3}$ / day) of its total faecal sludge at the Lavender Hill waste treatment facility in Accra [33]. Its closeness to Accra satisfied the Tricycle surveillance protocol's requirement of being in proximity to the capital city ( $2-4 \mathrm{~h}$ required for transport of samples to the laboratory).

The Okurudu River lies between two river basins: Ayensu towards the west and Densu towards the east. It flows through the city and discharges into Nyanyano lagoon, an outlet into the Atlantic Ocean. 
Upstream water samples from the Okurudu River were taken seven kilometres above the downstream sampling point. Communal waste (human wastewater) was sampled from an open drain located adjacent to a market characterised by heavy human activities, especially during its two market days. Animal waste was collected from a drain at a slaughter slab that deals in cattle, sheep and goats, while downstream samples were collected about seven kilometres away from the slaughter slab. Sampling points are shown on the map in Figure 1.

\subsection{Sample Site Selection}

Selection of sampling sites conformed to the WHO ESBL-Ec Tricycle Protocol [28] as shown in Table 1.

Table 1. ESBL-Ec Tricycle Protocol.

\begin{tabular}{|c|c|}
\hline & Summaries of Study Elements \\
\hline Number of Cities & Within One Country: Two Cities Should be Identified \\
\hline Eligible City & $\begin{array}{l}\text { Major (capital) city where the analysis laboratories are located. } \\
\text { This city must have a hospital health care facility and a wet } \\
\text { market for the study of the two other Tricycle work packages; } \\
\text { WP1 (ESBL-Ec in food chain) and WP2 (ESBL-Ec in humans). } \\
\text { As well as a sentinel city of about 100,000 inhabitants, in } \\
\text { proximity to the capital city. } \\
\text { Both require the presence of a river. }\end{array}$ \\
\hline $\begin{array}{l}\text { Who helps with the selection } \\
\text { of sites }\end{array}$ & $\begin{array}{l}\text { Within each city, the identification of collection sites for each } \\
\text { sample type will be performed with the assistance of other } \\
\text { authorities and specialists to identify the most representative } \\
\text { sampling sites. }\end{array}$ \\
\hline Sample points & $\begin{array}{l}\text { Four sample points from each city: } \\
\text { Two hotspot sources, an upstream and a downstream point on } \\
\text { rivers receiving wastewater from these cities. } \\
\text { River water upstream of the city, representing pre-city impacts } \\
\text { and other upstream activities in the catchment area-serves as } \\
\text { a reference sample to detect the influence from the city. } \\
\text { River water downstream of the city is representative of } \\
\text { city impacts } \\
\text { Communal waste (influent of a treatment plant, or major } \\
\text { collecting sewers) representing human faecal material. } \\
\text { Waste from a wet market (or slaughterhouse, if wet markets } \\
\text { are not present), representing animal faecal material. }\end{array}$ \\
\hline Sampling rounds & $\begin{array}{l}\text { Monthly sampling for one year. } \\
\text { Number of samples: } 2 \text { cities } \times 4 \text { samples } \times 8-12 \text { rounds } / \text { year } \\
=64-96 \text { samples. }\end{array}$ \\
\hline Analysis parameters & $\begin{array}{l}\text { Concentration of E. coli } \\
\text { Concentration of ESBL producing E. coli (ESBL-Ec) } \\
\text { Ratio ESBL-Ec over E. coli }\end{array}$ \\
\hline
\end{tabular}

\subsection{Sample Collection Period}

Water samples were collected for a total of 12 months, broken into three periods. August-December 2018, October-February 2020 and May, June 2020 partly due to COVID-19 restrictions.

\subsection{Sampling Method}

Samples were collected between 6.00 a.m. to 12:00 p.m. At each sampling point, composite water samples were taken with a bailer; three scoops per sample, $20-30 \mathrm{~cm}$ below the water surface, five minutes apart. Samples were immediately transferred into sterile Nalgene $500 \mathrm{~mL}$ bottles after each scoop. Each sample was given a unique identifier 
for traceability. Ambient water temperature, air temperature, and $\mathrm{pH}$ (Multi-Parameter PCSTestr ${ }^{\mathrm{TM}} 35$ Eutech Instruments OakTon) of the samples were recorded along with the sample location, and date (month and year) of collection. Water colour, flow rate and turbidity were also rated and scored. Details of each sample were entered immediately onto a field sampling sheet after which samples were stored in a cold chest at $4{ }^{\circ} \mathrm{C}$. All samples were transported to the laboratory and the information on each sample was entered into a Results Book at the laboratory. To access the laboratory in time for analysis to be carried out before $12 \mathrm{~h}$, each city was sampled on alternate days. Sampling methods also conformed to methods outlined in Standard Methods for the Examination of water and wastewater [37] and ISO 19458:2006IDT, Water quality-sampling for microbiological analysis [38].

All field sampling and laboratory analysis procedures were carried out at the microbiology unit of the Council for Scientific and Industrial Research-Water Research Institute (CSIR-WRI).

\subsection{Laboratory Procedures}

In the laboratory, samples were mixed vigorously and diluted serially 10-fold using sterile Phosphate Buffered Saline solution. Suitable dilutions were vortexed and filtered through sterile $0.45 \mu \mathrm{m}$ pore size membrane filters (MF-Millipore ${ }^{\mathrm{TM}}$ cellulose nitrate Membrane Filter). Filters were subsequently placed on both Tryptone Bile X-glucuronide medium (TBX) (Oxoid) and TBX supplemented with $4 \mu \mathrm{g} / \mathrm{mL}$ cefotaxime (TBX/CTX) and incubated at $37^{\circ} \mathrm{C}$ for 18-24 h [37]. Plates with counts less than or equal to 100 blue-green colonies recovered from both (TBX) (Oxoid) and TBX/CTX were counted with the aid of a colony counter $\left(\right.$ Stuart ${ }^{\circledR}$ SC6PLUS Digital Colony Counters, Stone, Staffordshire ST15 OSA (UK), United Kingdom). Five to eight cefotaxime resistant colonies from TBX supplemented media were streaked first for purity on TBX agar and subsequently on Nutrient Agar (oxoid) after $24 \mathrm{~h}$. Suspected E. coli isolates were further confirmed by Indole-testing using Kovacs reagent. Cefotaxime-resistant E. coli were screened phenotypically for ESBL-production using the double-disc diffusion method according to Clinical and Laboratory Standards Institute (CLSI, 2016, Wanye, Pennsylvania, USA using Cefotaxime/Clavulanic Acid $30 / 10 \mu \mathrm{g}$, Cefotaxime $30 \mu \mathrm{g}$, Ceftazidime $30 \mu \mathrm{g}$, and Ceftazidime/Clavulanic Acid 30/10 $\mu \mathrm{g}$ (Becton Dickenson $^{\mathrm{TM}}$ ) [39]. Ratio ESBL-Ec over E. coli were calculated following ISO 8199 Water Quality-General guidance on the enumeration of micro-organisms by culture [40].

\subsection{Quality Control Measures}

All media were prepared according to the manufacturer's instructions and the Tricycle Protocol. Each batch of media was pre-tested for sterility and the ability to support the growth of E. coli. Media and antibiotics were quality controlled using E. coli ATCC 25922, and Klebsiella pneumoniae ATCC 70063.

\subsection{Data Collection, Source of Data and Validation}

Study data were extracted from the Results Book of the Tricycle Project in the microbiology laboratory of CSIR-WRI and double entered into the study Excel database to ensure quality.

\subsection{Statistical Analysis}

Descriptive analysis was performed to show variations in the concentration of E. coli, ESBL-Ec and the percent ESBL-Ec/E. coli among all sampling sites. Normality of each dependent variable was tested using the Shapiro Wilk test. The Kruskal Wallis Sign Rank test was used to compare means of bacteria recovered among all four sampling sites while the Mann-Whitney U test was used to compare variations in bacterial concentration between the two cities. Physical parameters ( $\mathrm{pH}$ and temperature) at the study locations of the two cities were compared using the independent sample t-test with cities used as grouping variables. Levene's test was used to test for the equality of variance. All tests of statistical significance were set at a $p$-value of 0.05 . To test for statistically significant 
association between temperature, $\mathrm{pH}$ and bacterial count, Spearman's rank correlation was employed as bacterial data did not follow a normal distribution. The Statistical Package for Social Science (SPSS) software (IBM version 26) was used to perform all data analysis.

\section{Results}

Over the 12-month study period, 96 surface water samples were collected from the Odaw River located in Accra and the Okurudu River located in Kasoa.

\subsection{Physical Characteristics of Water Samples}

Overall, the mean ambient surface water temperatures in Accra ranged from $23.2{ }^{\circ} \mathrm{C}$ to $32.9{ }^{\circ} \mathrm{C}$ and in Kasoa from $25.8^{\circ} \mathrm{C}$ to $35.2^{\circ} \mathrm{C}$. The $\mathrm{pH}$ levels of water samples in Accra ranged from 6.68 to 8.70 and in Kasoa 6.32 to 8.40 .

When ambient water temperatures at each sample location were compared separately, variation was not significantly different among (1) downstream samples ( $p=0.277$ ) (Accra; Mean $=27.8 \pm 2.1{ }^{\circ} \mathrm{C}$, Kasoa; Mean $\left.=28.8 \pm 2.3{ }^{\circ} \mathrm{C}\right),(2)$ animal waste water samples $(p=0.098)$ (Accra; Mean = 29.3 $\pm 2.0^{\circ} \mathrm{C}$ Kasoa; Mean $\left.=29.5 \pm 2.76{ }^{\circ} \mathrm{C}\right)$ and $(3)$ human wastewater samples $(p=0.100)$ (Accra; Mean $=28.0 \pm 2.5^{\circ} \mathrm{C}$, Kasoa; Mean $=30.0 \pm 3.2^{\circ} \mathrm{C}$ ). Upstream water samples in both cities, however, showed significant variation in their ambient surface water temperatures $(p=0.005)$ (Accra; Mean $=26.85 \pm 1.2{ }^{\circ} \mathrm{C}$, Kasoa; Mean $=29.68 \pm 2.7^{\circ} \mathrm{C}$ ).

When ambient water $\mathrm{pH}$ at each sample location was compared, there were no significant differences among (1) downstream samples ( $p=0.107)$ (Accra; Mean $=7.76 \pm 0.22$, Kasoa; Mean = $7.92 \pm 0.18)$, (2) animal waste water samples $(p=0.092)$ (Accra; Mean = 7.87 \pm 0.48 , Kasoa; Mean $=7.43 \pm 0.63)$ and (3) human wastewater samples ( $p=0.092$ ) (Accra; Mean $=7.87 \pm 0.49$, Kasoa; Mean $=7.45 \pm 0.63$ ). Upstream water samples of both cities, however, showed significant differences in ambient water $\mathrm{pH}$ values $(p=0.012)$ (Accra; Mean $=7.60 \pm 0.49$, Kasoa; Mean $=8.07 \pm 0.28)$.

\subsection{E. coli Concentrations (cfu/100 mL) in Water Samples in Accra and Kasoa}

Figure 2 shows E. coli concentration per $100 \mathrm{~mL}$ compared with ESBL-Ec per $100 \mathrm{~mL}$ of sample water collected in Accra and Kasoa. Overall, animal waste collected from both cities had the highest $E$. coli concentration of $4.8(\mathrm{IQR}, 2.4-8.5) \times 10^{7} \mathrm{cfu} / 100 \mathrm{~mL}$ whilst upstream river samples had the lowest concentration of $1.8(\mathrm{IQR}, 1.0-3.9) \times 10^{4} \mathrm{cfu} / 100 \mathrm{~mL}$ (Table 2). These observations were similar for both cities. Accra, however, had a higher E. coli concentration of $4.0 \times 10^{6}\left(\mathrm{IQR}, 3.2 \times 10^{5}-6.8 \times 10^{7}\right)$ when all samples were considered together, but this was not statistically significant when compared to Kasoa: $5.6 \times 10^{5}\left(\mathrm{IQR}, 8.0 \times 10^{4}-7.7 \times 10^{6}\right)(p=0.23)($ Table 2$)$. Upstream E. coli concentrations were significantly greater in Kasoa at $2.9\left(\mathrm{IQR}, 1.9-5.3 \times 10^{4}\right)$ compared to Accra $1.1 \times 10^{4}$ $\left(\mathrm{IQR}, 7.2 \times 10^{3}-1.7 \times 10^{4}\right)(p=0.01)$. In contrast, significantly greater $E$. coli concentrations were found from Accra's downstream $5.0 \times 10^{6}\left(\mathrm{IQR}, 3.3 \times 10^{6}-6.7 \times 10^{6}\right)$ and human $4.5 \times 10^{6}\left(\mathrm{IQR}, 3.2 \times 10^{6}-2.1 \times 10^{7}\right)(p=0.04)$ wastewater samples compared to those of Kasoa's downstream: $3.8 \times 10^{5}$ (IQR $\left.2.0 \times 10^{2}-5.4 \times 10^{5}\right)$, and human: $5.4 \times 10^{5}(\mathrm{IQR}$, $\left.8.2 \times 10^{5}-5.5 \times 10^{6}\right)(p=0.00)$ wastewater (Figure 2). There were no significant differences in E. coli concentrations among animal wastewater samples in the two cities $(p=0.16)$. Throughout the study period, E. coli concentrations from each sampling point in both cities remained relatively constant as shown in Figure 3. There were no significant differences in bacterial counts between the wet and dry seasons. 
A

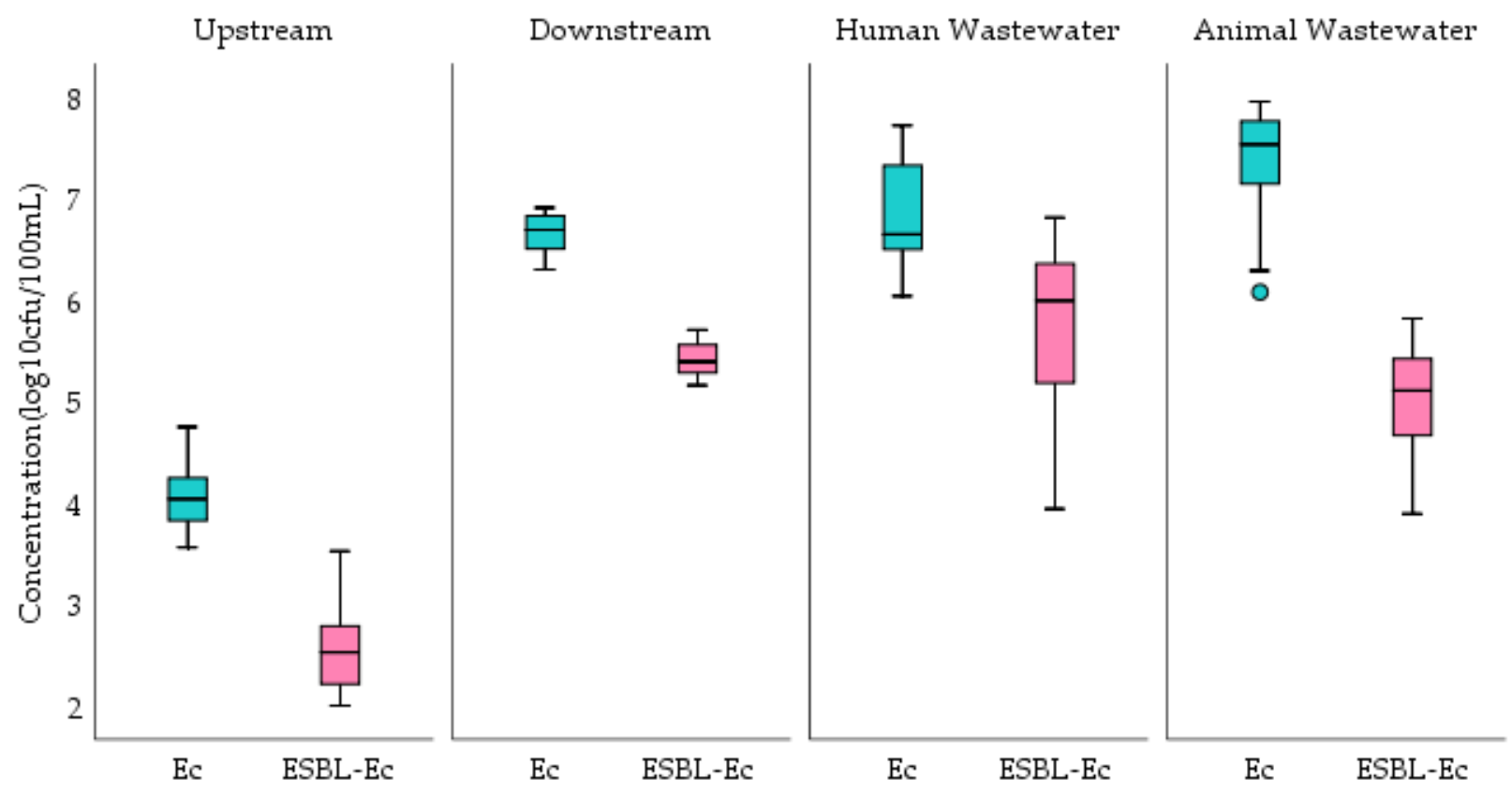

B

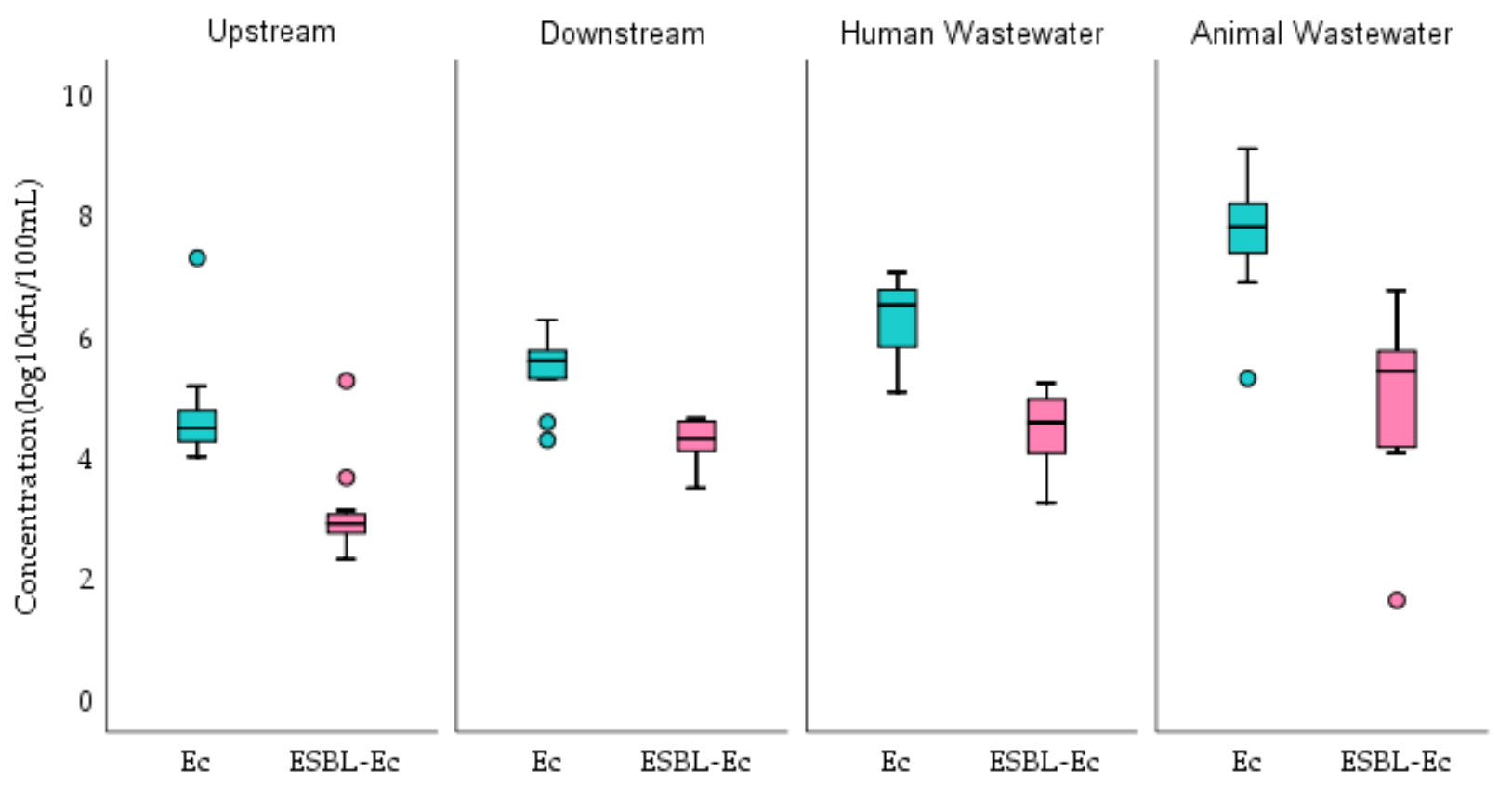

Figure 2. Comparison of concentrations of E. coli and ESBL-Ec among sampling sites in Accra (A) and Kasoa (B) for the periods of August 2018-December 2019, October 2019-February 2020, May, and Jun. 2020, Ec = E. coli, $\mathrm{ESBL}-\mathrm{Ec}=$ Extended-Spectrum Beta-Lactamase E. coli, $\mathrm{cfu}=$ colony forming units. 
Table 2. Concentrations of Escherichia coli (Ec), stratified by site, city, and season in water samples from Accra and Kasoa, Ghana, from August 2018-December 2019, October 2019-February 2020, May, and June 2020 .

\begin{tabular}{|c|c|c|c|c|c|}
\hline & Sample Type & Sample Number & Median Concentration & $\left(\mathrm{Q} 1^{\mathrm{b}}, \mathrm{Q} 2^{\mathrm{c}}\right)$ & \\
\hline & & (N) & $\left(E c^{a} c f u / 100 \mathrm{~mL} \times 10^{7}\right)$ & $\mathrm{cfu} / 100 \mathrm{~mL} \times 10^{7}$ & $P^{d}$ \\
\hline \multirow[t]{6}{*}{ Sites } & & & & & 0.00 \\
\hline & Upstream & 24 & 0.0018 & $(0.00096,0.0039)$ & \\
\hline & Downstream & 24 & 0.19 & $(0.037,0.54)$ & \\
\hline & $\begin{array}{c}\text { Human } \\
\text { wastewater }\end{array}$ & 24 & 0.37 & $(0.13,0.84)$ & \\
\hline & $\begin{array}{c}\text { Animal } \\
\text { wastewater }\end{array}$ & 24 & 4.8 & $(2.4,8.5)$ & \\
\hline & & & & & 0.86 \\
\hline \multirow{2}{*}{ Season } & Wet & 48 & 0.21 & $(0.0053,0.21)$ & \\
\hline & Dry & 48 & 0.32 & $(0.019,0.86)$ & 0 \\
\hline \multirow{2}{*}{ City } & Accra & 48 & 0.40 & $(0.032,2.3)$ & \\
\hline & Kasoa & 48 & 0.06 & $(0.008,0.77)$ & \\
\hline & Sample Total & 96 & 0.3 & $(0.008,1.8)$ & \\
\hline
\end{tabular}

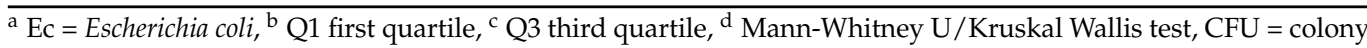
forming units.

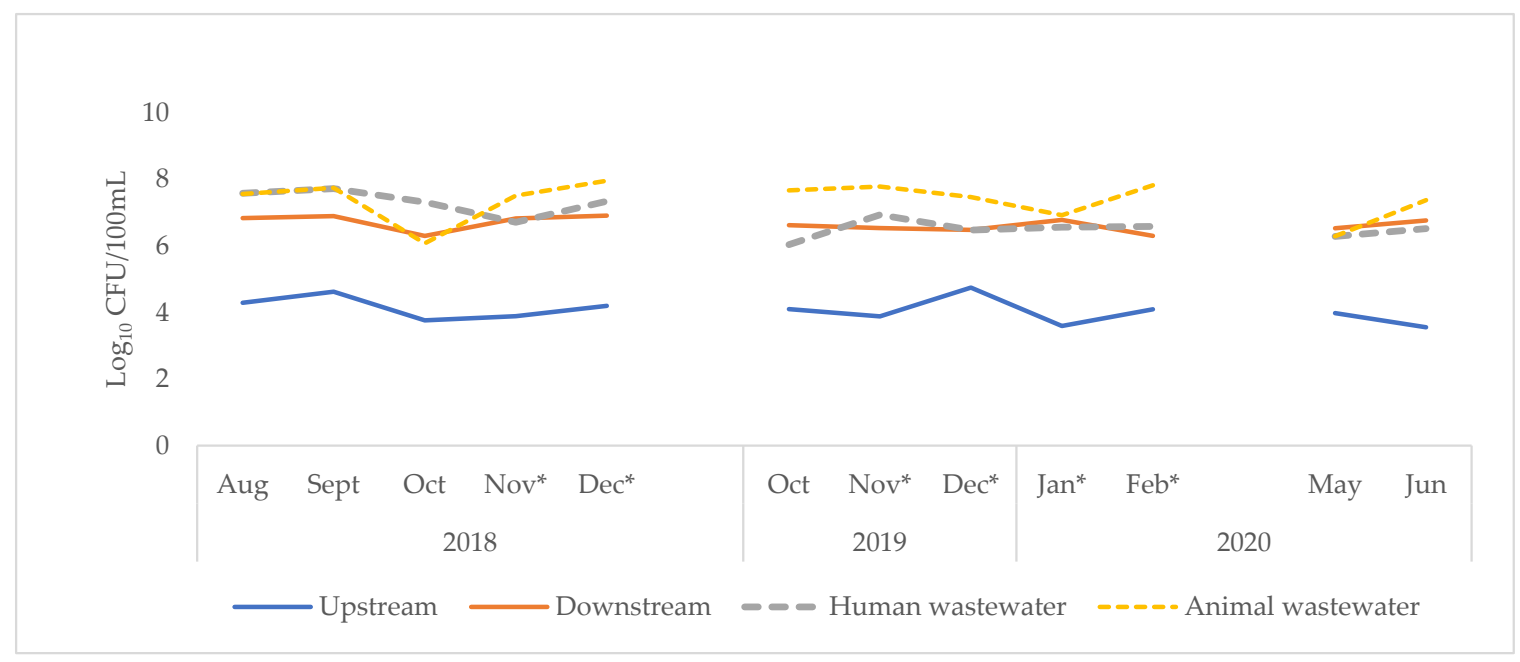

(A)

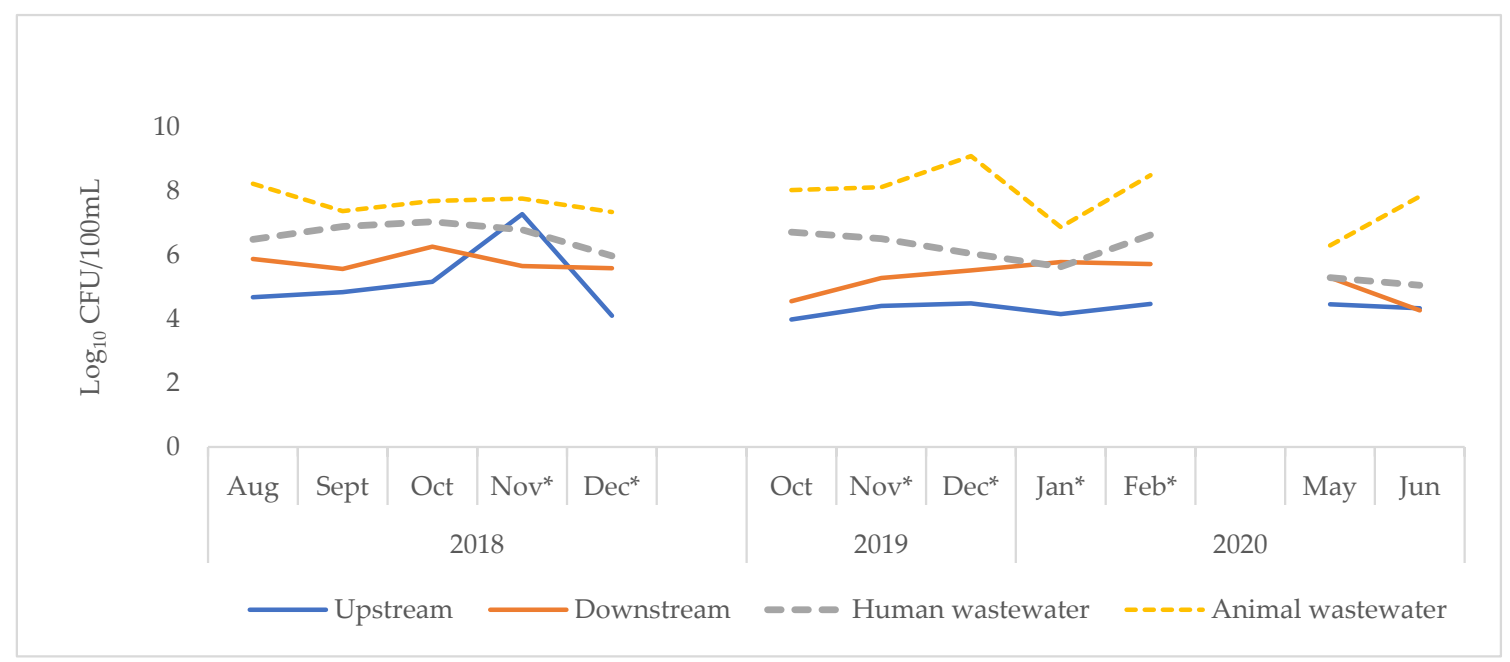

(B)

Figure 3. Log concentration of E. coli in sample sites of Accra (A) and Kasoa (B) for the periods: August 2018-December 2019, October 2019-February 2020, May, June 2020. * Indicates dry season, cfu = colony forming units. 
There was a weakly positive correlation between water temperature and E. coli concentrations $(\rho=0.248)$ significant at $p=0.015$ and a weakly negative correlation between $\mathrm{pH}$ and $E$. coli counts $(\rho=-0.355)$ at a significant figure of $p=0.001$.

\subsection{ESBL-Ec Concentrations (cfu/100 mL) in Water Samples in Accra and Kasoa}

ESBL-Ec were present in almost all samples analyzed-94 (98\%). When sampling points from both cities were considered collectively, animal wastewater had the highest concentration of ESBL-Ec per sample at $1.8(\mathrm{IQR}, 0.3-3.9) \times 10^{5} \mathrm{cfu} / 100 \mathrm{~mL}$ whilst upstream surface water samples had the least concentration at $6.0 \times 10^{2}\left(\mathrm{IQR}, 2.3 \times 10^{2}-9.2 \times 10^{2}\right) \mathrm{cfu} / 100 \mathrm{~mL}$ (Table 3). The ESBL-Ec concentration from each sampling point followed a similar pattern over the study period in both cities (Figure 4). However, significantly higher concentrations of ESBL-Ec were observed in samples from Accra: $1.7 \times 10^{5}\left(\mathrm{IQR}, 4.4 \times 10^{3}-3.0 \times 10^{5}\right)$ compared to Kasoa: $1.5 \times 10^{4} \mathrm{cfu} / 100 \mathrm{~mL}\left(\mathrm{IQR}, 2.0 \times 10^{3}-9.0 \times 10^{4}\right)(p=0.03)$ (Table 3).

Table 3. Concentrations of ESBL-Ec a , stratified by site, city and season of water samples from Accra and Kasoa, Ghana, from August 2018-December 2019, October 2019-February 2020, May, and June 2020.

\begin{tabular}{|c|c|c|c|c|c|}
\hline & Sample Type & Sample Number & Median Concentration & $\left(\mathrm{Q} 1^{\mathrm{b}}, \mathrm{Q} 2^{\mathrm{c}}\right)$ & \\
\hline & & (N) & $\begin{array}{c}\text { (ESBL-Ec) }^{a} \\
\mathrm{cfu} / 100 \mathrm{~mL} \times 10^{4}\end{array}$ & $\mathrm{cfu} / 100 \mathrm{~mL} \times 10^{4}$ & $\mathbf{P}^{\mathbf{d}}$ \\
\hline \multirow[t]{5}{*}{ Sites } & & & & & 0.00 \\
\hline & Upstream & 24 & 0.061 & $(0.023,0.092)$ & \\
\hline & Downstream & 24 & 9.30 & $(1.90,25)$ & \\
\hline & $\begin{array}{c}\text { Human } \\
\text { wastewater }\end{array}$ & 24 & 8.80 & $(1.50,47)$ & \\
\hline & $\begin{array}{c}\text { Animal } \\
\text { wastewater }\end{array}$ & 24 & 18 & $(2.7,39)$ & \\
\hline \multirow[t]{3}{*}{ Season } & & & & & 0.94 \\
\hline & Wet & 48 & 3.5 & $(0.31,25)$ & \\
\hline & Dry & 48 & 4.3 & $(0.35,23)$ & \\
\hline \multirow[t]{4}{*}{ City } & & & & & 0.03 \\
\hline & Accra & 48 & 17 & $(0.44,30)$ & \\
\hline & Kasoa & 48 & 1.5 & $(0.20,9.0)$ & \\
\hline & Sample Total & 96 & 4.2 & $(0.31,23)$ & \\
\hline
\end{tabular}

a ESBL-Ec-Extended Spectrum Beta-lactamase Escherichia coli, ${ }^{\mathrm{b}} \mathrm{Q} 1$ first quartile, ${ }^{\mathrm{c}} \mathrm{Q} 3$ third quartile, ${ }^{\mathrm{d}}$ MannWhitney $\mathrm{U} /$ Kruskal Wallis test, $\mathrm{CFU}=$ colony-forming units.

The ESBL-Ec concentrations were significantly higher $(p=0.03)$ in upstream waters of Kasoa: 7.8 (IQR, 6.4-10) $\times 10^{2}$ compared to upstream waters in Accra: $3.5(\mathrm{IQR}, 1.6-6.1) \times 10^{2}$, $(p=0.03)$ (Figure 2$)$. ESBL-Ec concentrations however, were significantly higher $(p=0.00)$ in downstream: 2.5 (IQR, 2.0-3.3) $\times 10^{5}$ and in human wastewater: 4.2 (IQR 0.8-9.3) $\times 10^{5}$ in Accra compared to Kasoa: downstream: 2.0 (IQR, 1.4-3.7) $\times 10^{4}$ and human wastewater: 3.7 (IQR, 1.3-8.6) $\times 10^{4}$ (Figure 2). There were no significant differences in ESBL-Ec concentrations between animal wastewater samples from both cities. (Figure 2). ESBL-Ec correlations with temperature and $\mathrm{pH}$ were not statistically significant.

In all, there was a strong positive association between E. coli and ESBL-Ec counts in $\mathrm{cfu} / 100 \mathrm{~mL}(\mathrm{r}=0.761, p=0.000)$. 


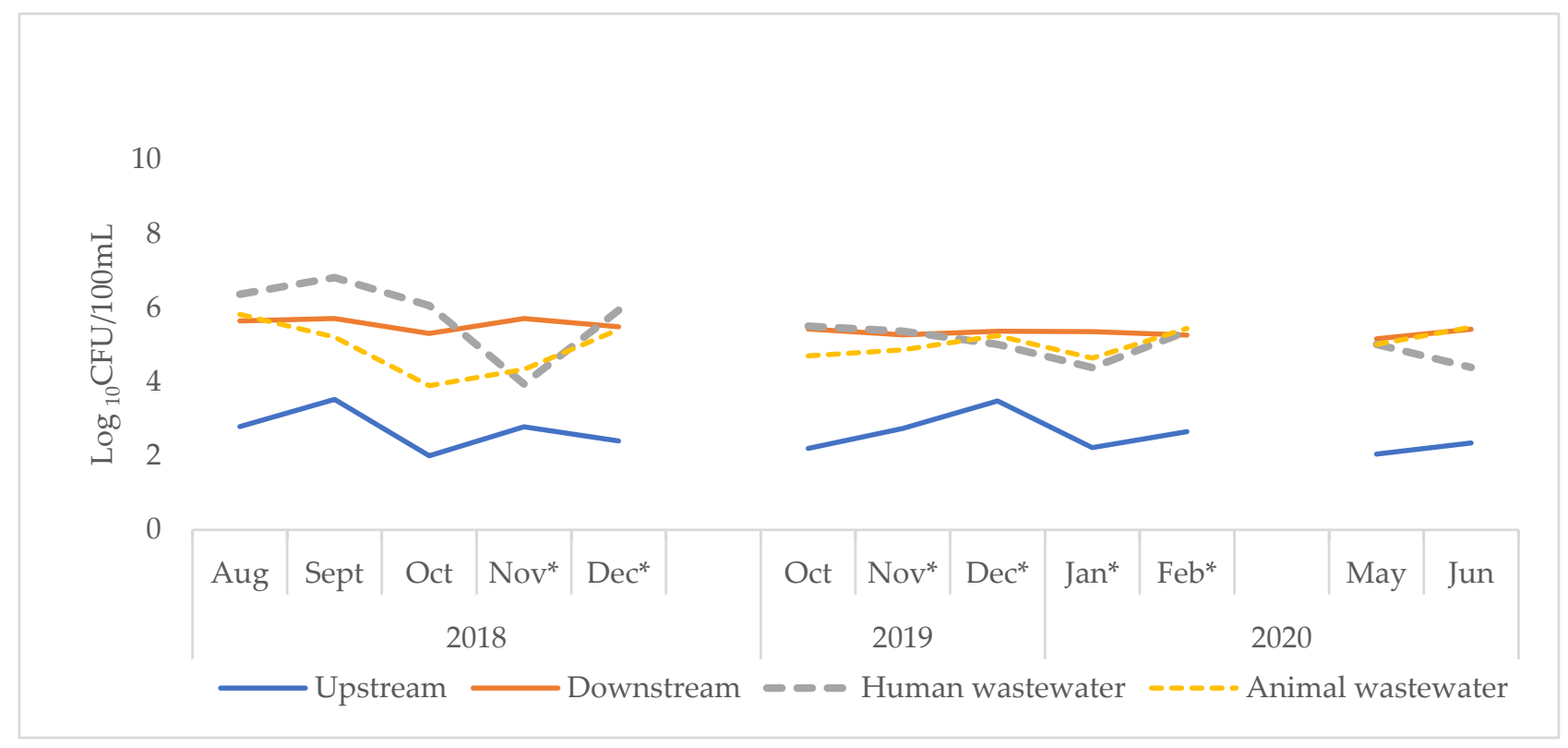

(A)

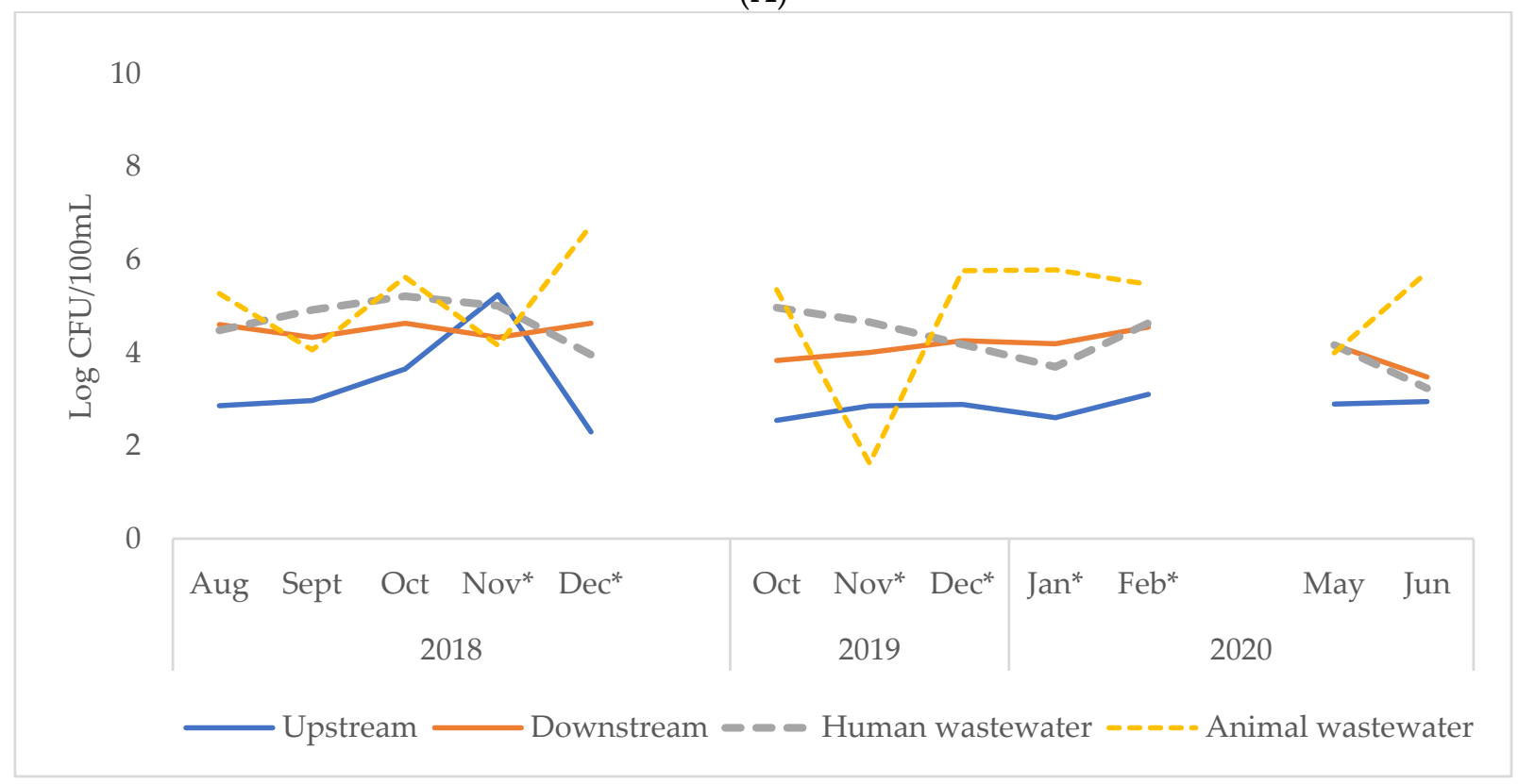

(B)

Figure 4. Log concentration of ESBL-Ec in sampling sites in Accra (A) and Kasoa (B) for the periods: August 2018-December 2019, October 2019-February 2020, May, June 2020. * Indicates dry season, ESBL-Ec = Extended-Spectrum Beta-Lactamase E. coli, $\mathrm{CFU}=$ colony-forming units.

\subsection{Percentage ESBL-Ec (cfu/100 mL) Concentrations in Water Samples in Accra and Kasoa}

Figure 5 shows the proportion of ESBL-Ec among the total number of E. coli isolated per sample from Accra and Kasoa. Overall, the proportion of ESBL-Ec/E. coli isolates per sample from both cities was $2.79 \%$ (IQR, 1.04-6.03) (Table 4). The highest proportion of ESBL-Ec was obtained from downstream water samples at $6.06 \%$ (IQR, 4.57-7.64), and the lowest was from animal wastewater at $0.30 \%$ (IQR, 0.10-0.84) (Table 4). Upstream samples had a relatively lower percentage ESBL-Ec/Ec at 2.93\% (IQR, 1.58-4.29) compared to downstream water samples. Samples from Accra generally had a higher proportion of ESBL-Ec at $4.08 \%$ (1QR, 0.78-6.37) compared to Kasoa at 2.06\% (IQR, 0.99-5.32). Over the 
study period, the proportion of ESBL-Ec isolated per sample fluctuated significantly across both study sites (Figure 6). There was a weak negative correlation between temperature and percentage ESBL-Ec $(-0.294)$ at a significant value of $p=0.004$ and a weak positive correlation between $\mathrm{pH}$ and percentage ESBL-Ec (0.215) at a significant value of $(0.044)$.

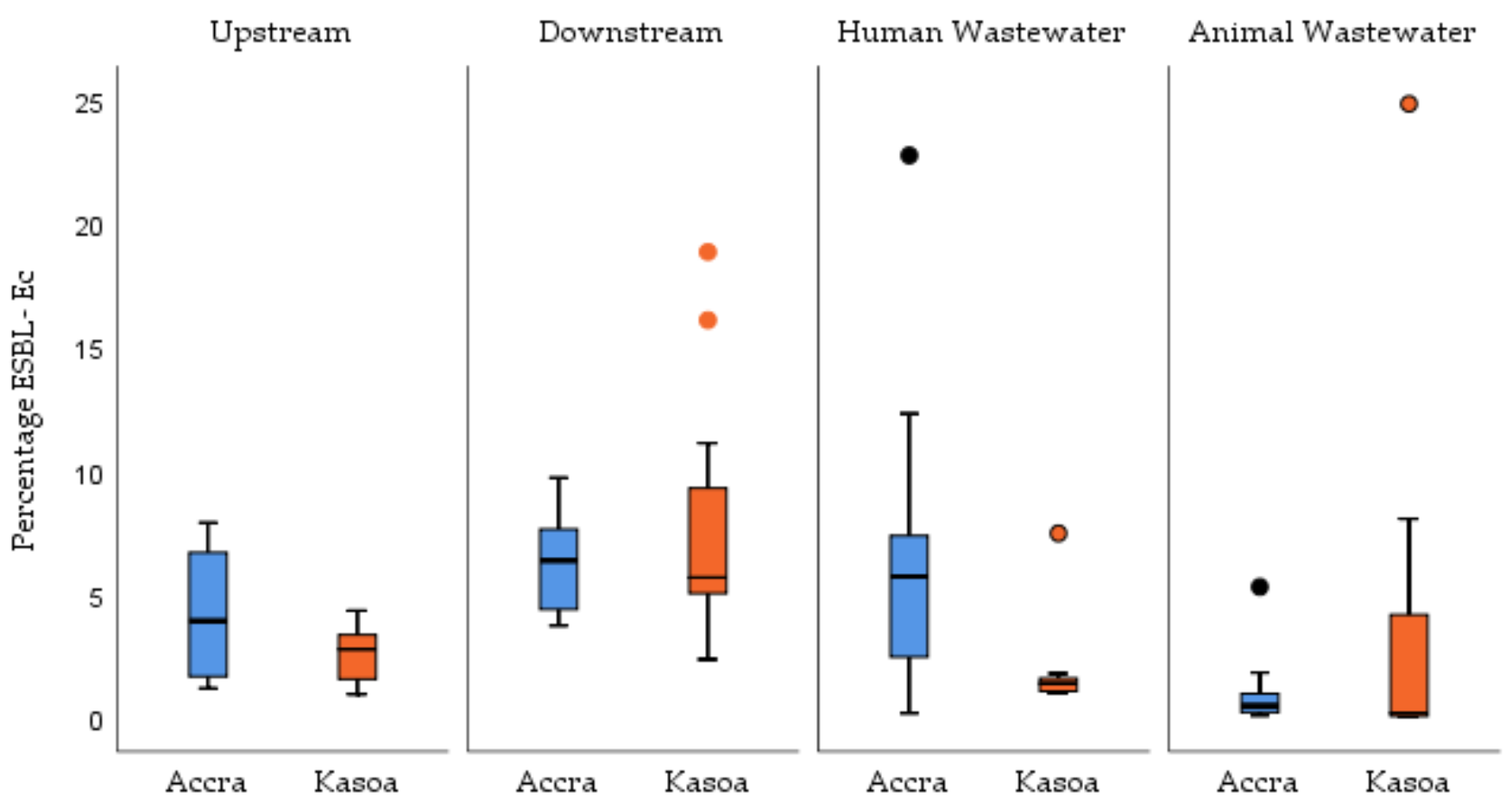

Figure 5. Comparison of percent ESBL-Ec in Accra and Kasoa or the periods of August 2018-December 2019, October 2019-February 2020, May, and June 2020, ESBL-Ec = Extended-Spectrum Beta-Lactamase E. coli.

Table 4. \%ESBL-Ec, stratified by site, city and season of water samples from Accra and Kasoa, Ghana, from August 2018-December 2019, October 2019-February 2020, May, and June 2020.

\begin{tabular}{|c|c|c|c|c|c|}
\hline & Sample Type & $\begin{array}{l}\text { Sample } \\
\text { Number }\end{array}$ & $\begin{array}{c}\text { Median } \\
\text { Proportion }\end{array}$ & $\left(\mathrm{Q} 1^{\mathrm{b}}, \mathrm{Q} 2^{\mathrm{c}}\right)$ & \\
\hline & & (N) & $(\% \text { ESBL-Ec) })^{a}$ & $(\mathrm{cfu} / 100 \mathrm{~mL})$ & $P^{d}$ \\
\hline \multirow[t]{5}{*}{ Sites } & & & & & 0.00 \\
\hline & Upstream & 24 & 2.93 & $(1.57,4.29)$ & \\
\hline & Downstream & 24 & 6.06 & $(4.57,7.64)$ & \\
\hline & $\begin{array}{c}\text { Human } \\
\text { wastewater }\end{array}$ & 24 & 1.58 & $(1.04,6.00)$ & \\
\hline & $\begin{array}{c}\text { Animal } \\
\text { wastewater }\end{array}$ & 24 & 0.30 & $(0.10,0.84)$ & \\
\hline \multirow[t]{3}{*}{ Season } & & & & & 1.00 \\
\hline & Wet & 48 & 2.53 & $(1.00,6.10)$ & \\
\hline & Dry & 48 & 3.20 & $(0.93,6.01)$ & \\
\hline \multirow[t]{4}{*}{ City } & & & & & 0.07 \\
\hline & Accra & 48 & 4.08 & $(0.79,6.37)$ & \\
\hline & Kasoa & 48 & 2.06 & $(0.99,5.32)$ & \\
\hline & Sample Total & 96 & 2.79 & $(0.96,6.03)$ & \\
\hline
\end{tabular}

$\overline{{ }^{a} \text { ESBL-Ec-Extended Spectrum Beta-lactamase Escherichia coli, }{ }^{\mathrm{b}} \mathrm{Q} 1 \text { first quartile, }{ }^{\mathrm{c}} \mathrm{Q} 3 \text { third quartile, }{ }^{\mathrm{d}} \text { Mann- }}$ Whitney U/Kruskal Wallis test, $\mathrm{CFU}=$ colony-forming units. 


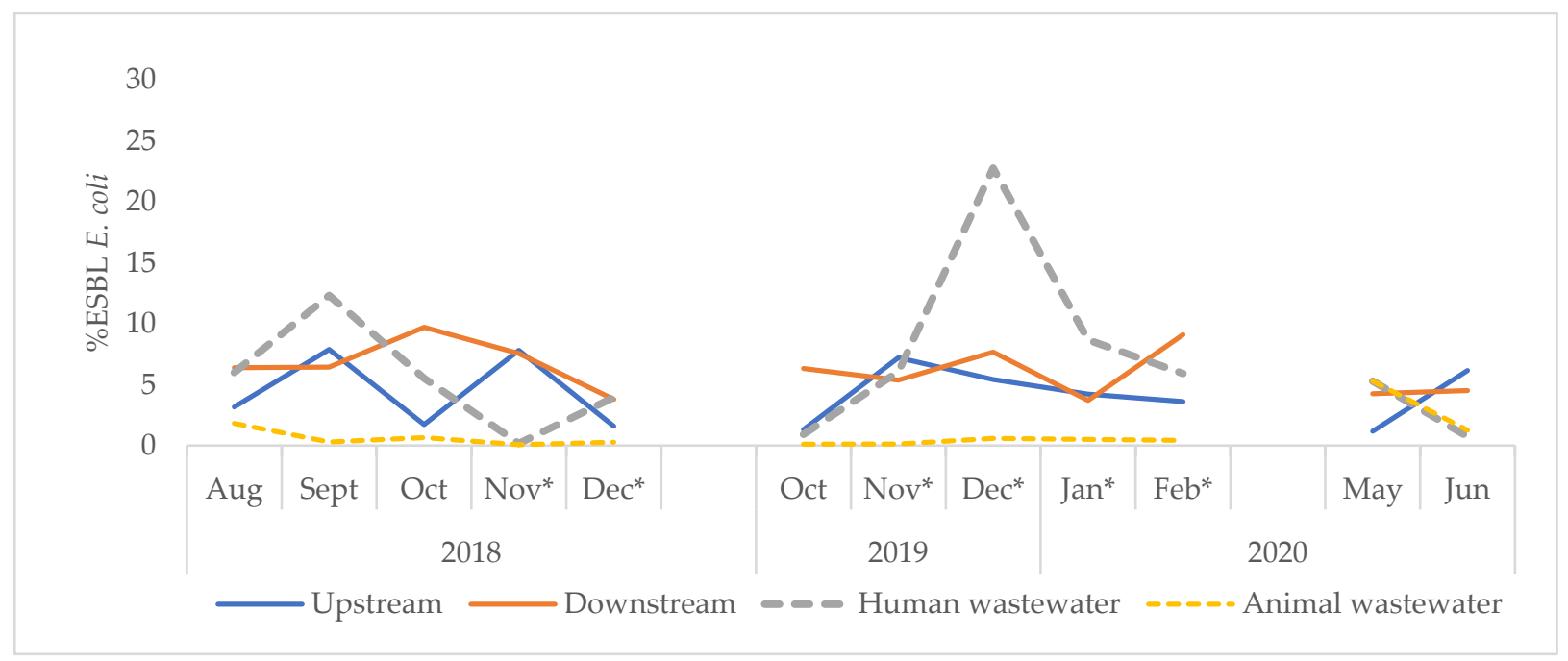

(A)

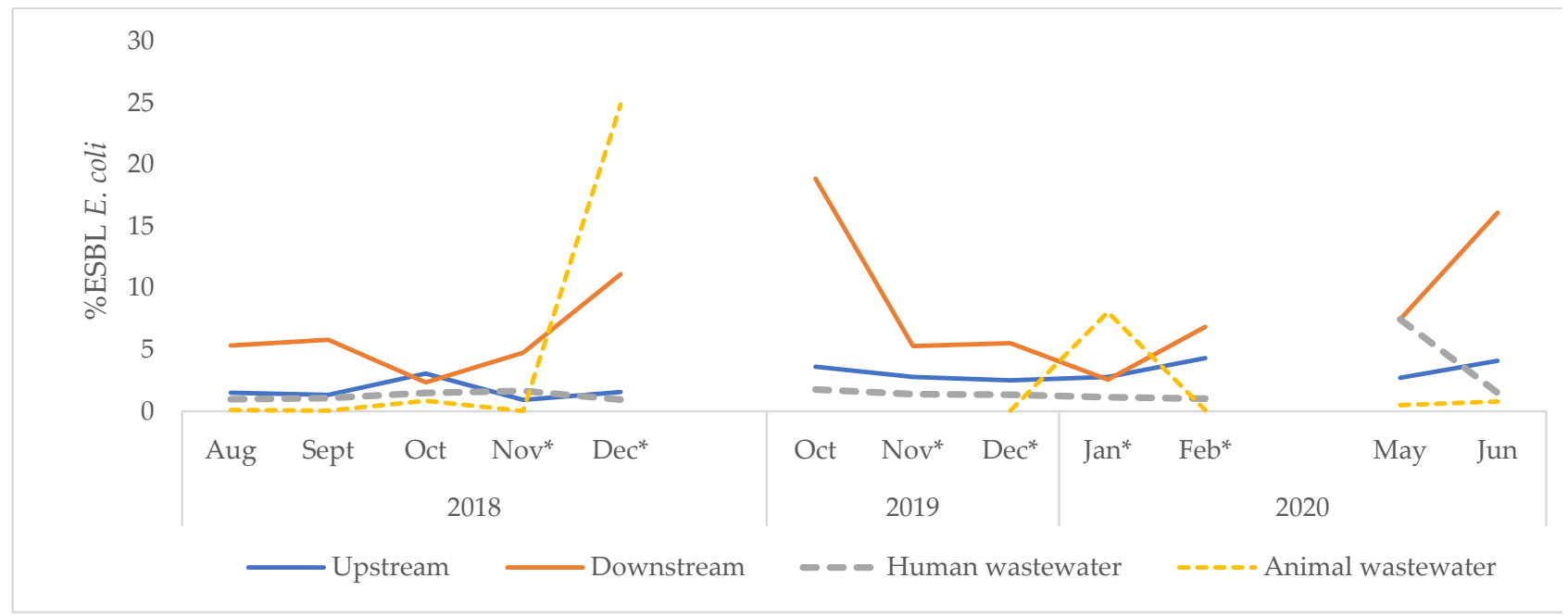

(B)

Figure 6. Proportion of ESBL-Ec among all E. coli in sites in Accra (A) and Kasoa (B) for the periods of August 2018December 2019, October 2019-February 2020, May and June 2020. * Indicates dry season, ESBL-Ec = Extended-Spectrum Beta-Lactamase E. coli.

\section{Discussion}

In rivers flowing through two cities in Ghana, we showed high concentrations of E. coli and relatively low but significant concentrations of ESBL-Ec cfu/100 $\mathrm{mL}$ from all water samples collected. The counts increased significantly from upstream to downstream, indicating that considerable contamination was taking place as the rivers flowed through the two cities.

In both Accra and Kasoa, almost all water samples recorded E. coli levels significantly above $\mathrm{WHO}$ guideline thresholds: $\leq 10^{4}$ E. coli counts per $100 \mathrm{~mL}$ are allowed for restricted irrigation of crops that require labour-intensive high contact agriculture and $\leq 10^{3}$ for unrestricted irrigation of root crops that may be eaten uncooked [41]. Counts were also much higher than Ghana's standard limits (E. coli $\leq 10 \mathrm{cfu} / 100 \mathrm{~mL}$ ) for discharge of wastewater into the environment [42]. E. coli concentrations in downstream water (4.3 (IQR, 3.5-4.7) $\log _{10} \mathrm{cfu} / \mathrm{mL}$ ) were slightly higher than those found from downstream water in South Africa (3.6-3.8 $\log _{10} \mathrm{cfu} / \mathrm{mL}$ ) [43], and lower compared to surface water in Kanpur, India $\left(5.1 \log _{10} \mathrm{cfu} / \mathrm{mL}\right)[26]$. 
In our study, almost all samples, i.e., 98\%, were positive for ESBL-Ec. Other studies have shown relatively lower ESBL-Ec recovery rates of $79.7 \%$ from untreated wastewaters in Nigeria [21], 28.6\% from wastewater and recipient surface waters from a treatment plant in South Africa [43], 64\% from environmental water sources in India and 59\% from different aquatic sources in Nicaragua [44].

In our study, increased contamination of downstream by and ESBL-Ec compared to upstream water was probably due to wastewater discharges into the rivers in populated areas [43]. In a recent study in Accra that assessed faecal exposure by comparing variation in $E$. coli counts from urban open drains of four neighborhoods, the $E$. coli concentrations were lower in improved (>85\%) sanitation coverage neighborhoods with high-income and lower population density and higher in poor $(<50 \%)$ sanitation coverage neighborhoods with low-income and higher population density. E. coli counts (>4 log10 CFU/100 mL) recovered from the two population categories are enough to pose a public health hazard [45]. In Ghana, like most LMICs, drainage systems consist of street gutters and storm drains that are not covered, making them very prone to runoff from all sources [46]. The absence of functioning sewer drainage systems in most homes results in untreated greywater and black water from septic tanks being discharged into the environment [47].

While there were no differences in E. coli concentrations between the two cities, the concentration of ESBL-Ec per $100 \mathrm{~mL}$ of sample in Accra was $2.5 \log$ units higher than in Kasoa. These differences could be due to two causes. First, there may be higher levels of community carriage of ESBL-Ec among the population of the catchment area in Accra, presumably from human and animal waste that is discharged without treatment into the rivers. For example, high carriage of ESBL-Ec among humans was found in Korle-Gonno96.4\% (134/139), a suburb of Accra with drains connected to the Odaw River [16]. Second, the rivers themselves could have differing concentrations of ESBL-Ec before entering the cities. In fact, the proportion of ESBL-Ec to E. coli was already higher in the upstream location of Accra as compared to Kasoa, as was the proportion of ESBL-Ec in human waste. It is also expected that Accra, being a larger city with more human and animal wastewater, would have a higher count of ESBL-Ec in its downstream waters than Kasoa.

Information on risk factors for ESBL-Ec carriage is mostly available for highly developed countries and includes consumption of antibiotics and recent hospitalisation [48]. It is likely that antibiotic use is also a determinant for ESBL-Ec carriage in Ghana; however, how it compares to other risk factors like human-animal contact or travel to other countries remains to be determined. ESBL-Ec can easily be transmitted between household members, so higher ESBL-Ec proportions might be maintained by higher population densities or tighter housing conditions [49]. Finally, an increased risk for ESBL-Ec acquisition during treatment of children with malnutrition has been found during amoxicillin therapy in Niger so the degree of malnourishment in the population might affect overall ESBL-Ec carriage [50]. The difference in ESBL proportions between the more urbanized Accra region and Kasoa also deserves further attention.

There were large variations in proportions of ESBL-Ec among E. coli from both cities 2.79 (IQR, 0.96-6.03\%). This was comparable to variations in the proportion of ESBL-Ec (0.1-19\%) from a French community effluent [51]. Among sampling points, the highest percentage of ESBL-Ec was found in the downstream water while the lowest was found in the animal wastewater. Thus, other sources, including human waste, probably contribute to increased ESBL-Ec presence in the downstream samples. The low proportions of ESBL-Ec concentrations among $E$. coli seen in this study are similar to other contexts such as $1.7 \%$ that has been found in a city wastewater, $0.2 \%$ in a slaughterhouse wastewater, $0.2 \%$ in a treated effluent in France [52] and 1\% from a constructed wetland also in France [53]. Occurrence of AMR bacteria in sub-quantities is known to create ideal conditions for bacteria to fix genes and to allow for gene amplification [54] and should not be underrated.

Generally, climatic conditions (temperature and $\mathrm{pH}$ ) in both cities during the study period were conducive for bacteria growth. The prevailing $\mathrm{pH}$ of ambient water provides an optimum growth range for most bacteria and falls within the USEPA Recommended 
Water Quality Criteria for Aquatic Life (6.5-8.5) [55]. E. coli has been shown to have a significant negative correlation with $\mathrm{pH}$ in water columns [56]. Though consistent with our findings, our correlation of $E$. coli with $\mathrm{pH}$ was not significant. Greater counts of bacteria recovered in the upstream water of Kasoa compared to Accra suggests relatively better protection of the source waters of Accra compared to Kasoa. Removal of riparian vegetation causes an increase in temperature of water and sediments and this facilitates coliform and E. coli survival and growth [57]. In general, the occurrence of coliform bacteria are significantly higher when water temperatures are above $15^{\circ} \mathrm{C}$ [58]. However, temperature overall only had a modest effect on absolute concentrations of ESBL-Ec. in our study. There were also no significant differences in bacterial counts between the wet and dry seasons, as has been shown by other studies $[59,60]$.

Ghana is one of the pilot countries in which the Tricycle Protocol was investigated with respect to its feasibility. Our results showed that the Protocol could easily be established in the CSIR-WRI laboratory and that it was clear, sufficiently detailed and specific. The laboratory's experience of E. coli testing as a water quality indicator and methods for its quantification (specifically, membrane filtration) helped the implementation of the Tricycle methodology. The Protocol is targeted towards implementation under circumstances without the presence of advanced laboratory infrastructure (e.g., MALDI-TOF for confirmation of species obtained) but nevertheless is expected to give results of high specificity through the use of assays based on the beta-glucuronidase activity of $E$. coli, which have a high sensitivity and specificity for determining E. coli concentrations in water. [61,62].

The strengths of this study were: first, we followed standardised methods for collecting and analysing the water samples. Second, all water samples collected were accounted for in the results. Third, the laboratory where the samples were processed is routinely monitored by the Eurofins proficiency testing scheme [63]. Finally, the conduct and reporting of the study adhered to Strengthening The Reporting of Observational Studies in Epidemiology (STROBE) guidelines [64].

There were some limitations of the study. First, more sampling sites could have been chosen to increase the precision of the location of ESBL-Ec contamination. Second, the breaks in the planned 12-month continuous testing plan resulted in the testing being carried out in three sections. This meant that variations due to wet and dry seasons could not be demonstrated. Third, measuring additional physicochemical parameters during sampling events may have given more clues to the growth of resistant $E$. coli as temperature and $\mathrm{pH}$ are not the only such influences on bacterial growth. Fourth, a full profile of antimicrobial susceptibility testing was not done that would have highlighted the level of multi-drug resistance among these organisms. Fifth we did not take into consideration the possible occurrence of glucuronidase negative $E$. coli as we dealt mainly with wastewater and not potable water samples.

This study has several implications. It has shown presence of ESBL-Ec in water bodies with the potential to transmit to humans and animals. Hitherto, the strategy for controlling AMR has focused on managing the use of antibiotics in humans and animals. This study points to environmental contamination as a potential source for AMR and suggests transmission related to such environmental contamination should be explored further. A relevant follow-up study would be to perform genetic analysis of the ESBL-Ec types found in humans and animals to see whether they correlate with types observed in the river.

Reducing environmental contamination could be achieved through improvements of the basic sanitation infrastructure and in household toilets for the population to reduce the practice of open defecation. It should also include improving the number and efficiency of sewage treatment plants. However, given limited budgets, this is unlikely to happen soon. In the short term, there is an urgent need to educate the population living around the rivers regarding the risks of using that water for domestic purposes and the need to render it safe before its use. Education should focus on reducing the practice of discharging untreated waste into water bodies. 


\section{Conclusions}

This study revealed high levels of $E$. coli and a significant concentration of ESBLEc in rivers flowing through two cities in Ghana. Both counts increased during their passage through the cities indicating contamination by human and animal wastewater. This situation may contribute to the spread of AMR among humans and animals in Ghana and should be considered a factor for further study. The Tricycle Protocol demonstrated its feasibility in a context like Ghana and the data gathered will serve as a good baseline for comparison with future studies.

Author Contributions: Conceptualization, J.M.A. and H.S.; Methodology, J.M.A., H.S., R.A.B., M.B.M., A.J.R., W.E.; Software, R.A.B., H.S., M.Y.O.-A., H.D.; Validation, H.S., J.M.A.; Formal Analysis, R.A.B., H.S., H.D., P.O.; Investigation, R.A.B., S.B., L.A.B.A., H.A., M.B.M., M.O.A., M.Y.O.A., G.Q.; Resources, J.M.A., H.S., E.A.A., E.D.O.A., M.Y.O.-A., M.B.M.; Draft Preparation, R.A.B.; Writing-Review \& Editing, R.A.B., A.J.R., W.E., A.-K.L.; Visualization, R.A.B., A.J.R., W.E., A.-K.L.; Supervision, E.D.O.A., M.B.M., A.J.R., W.E., A.-K.L., D.O., B.K., E.A.A., G.K.H.; Project Administration, R.A.B., S.B., L.A.B.A., H.A., M.B.M., M.O.A., G.Q.; Funding Acquisition, J.M.A., H.S., E.A.A., M.Y.O.-A., G.K.H. All authors have read and agreed to the published version of the manuscript.

Funding: This SORT IT AMR Programme was funded by National Institute of Health Research, Department of Health \& Social Care of the United Kingdom and supported by implementing partners.

Institutional Review Board Statement: The study received ethics approval from the Ethical and Protocol Review Board of the Ghana Health Service with approval number GHS-ERC005/08/18. Permissions were obtained from the Municipal Directors and environmental officers of the districts in which samples were taken. No human subjects were involved and hence there were no consents obtained. The study was also approved by the Ethics Advisory Group of the International Union against Tuberculosis and Lung Disease, Paris, France (approval No 78/19 dated 22 October 2019).

Informed Consent Statement: Not applicable.

Data Availability Statement: Data is available on request.

Acknowledgments: This research was conducted through the Structured Operational Research and Training Initiative (SORT IT), a global partnership coordinated by TDR, the Special Programme for Research and Training in Tropical Diseases at the World Health Organization (TDR). The specific SORT IT program that led to these publications included a partnership of TDR with WHO Country offices of Ghana, Sierra Leone and Uganda and was implemented along with The Tuberculosis Research and Prevention Center Non-Governmental Organization, Armenia; The International Union Against Tuberculosis and Lung Diseases, Paris and South East Asia offices; Institute of Tropical Medicine, Antwerp, Belgium; Sustainable Health Systems, Freetown, Sierra Leone; Médecins Sans FrontièresLuxembourg (LuxOR) Centre National de Formation et de Recherche en Santé Rurale de Maferinyah, Guinea; BahirDar University BahirDar, Ethiopia and the University of Salford, United KingdomWe also thank Government of the United Kingdom, using UK aid funding through the Fleming Fund, for funding the development and implementation of the Tricycle Protocol; the Advisory Group on Integrated Surveillance of Antimicrobial Resistance (AGISAR), the WHO Department of Surveillance Prevention and Control of AMR for their lead roles and numerous support; and the WHO Ghana country office for all their ongoing support. The geospatial and mapping portions of this publication.

Conflicts of Interest: The authors declare no conflict of interest. The funders had no role in the design of the study; in the collection, analyses, or interpretation of data; in the writing of the manuscript, or in the decision to publish the results.

\section{References}

1. WHO. Global Action Plan on Antimicrobial Resistance; World Health Organization: Geneva, Switzerland, 2017; pp. 1-28. Available online: https:/ / www.paho.org/en/documents/global-action-plan-antimicrobial-resistance-2017 (accessed on 20 June 2021).

2. World Organization for Animal Health. The OIE Strategy on Antimicrobial Resistance and the Prudent Use of Antimicrobials. 2016, pp. 1-61. Available online: https://www.oie.int/app/uploads/2021/03/en-oie-amrstrategy.pdf (accessed on 20 June 2021).

3. Founou, R.C.; Founou, L.L.; Essack, S.Y. Clinical and economic impact of antibiotic resistance in developing countries: A systematic review and meta-analysis. PLoS ONE 2017, 12, e0189621. [CrossRef] 
4. Ayukekbong, J.A.; Ntemgwa, M.; Atabe, A.N. The threat of antimicrobial resistance in developing countries: Causes and control strategies. Antimicrob. Resist. Infect. Control 2017, 6, 47. [CrossRef]

5. Obaidat, M.M.; Al-Zyoud, A.A.; Bani Salman, A.E.; Davis, M.A. Antimicrobial use and resistance among commensal Escherichia coli and Salmonella enterica in rural Jordan small ruminant herds. Small Rumin. Res. 2017, 149, 99-104. [CrossRef]

6. Tadesse, B.T.; Ashley, E.A.; Ongarello, S.; Havumaki, J.; Wijegoonewardena, M.; González, I.J.; Dittrich, S. Antimicrobial resistance in Africa: A systematic review. BMC Infect. Dis. 2017, 17, 1-17. [CrossRef]

7. Ogura, Y.; Ueda, T.; Nukazawa, K.; Hiroki, H.; Xie, H.; Arimizu, Y.; Hayashi, T.; Suzuki, Y. The level of antimicrobial resistance of sewage isolates is higher than that of river isolates in different Escherichia coli lineages. Sci. Rep. 2020, 10, 17880. [CrossRef]

8. Haberecht, H.B.; Nealon, N.J.; Gilliland, J.R.; Holder, A.V.; Runyan, C.; Oppel, R.C.; Ibrahim, H.M.; Mueller, L.; Schrupp, F.; Vilchez, S.; et al. Antimicrobial-Resistant Escherichia coli from Environmental Waters in Northern Colorado. J. Environ. Public Health 2019. [CrossRef] [PubMed]

9. Paulshus, E.; Kühn, I.; Möllby, R.; Colque, P.; O’Sullivan, K.; Midtvedt, T.; Lingaas, E.; Holmstad, R.; Sørum, H. Diversity and antibiotic resistance among Escherichia coli populations in hospital and community wastewater compared to wastewater at the receiving urban treatment plant. Water Res. 2019, 161, 232-241. [CrossRef] [PubMed]

10. Blaak, H.; De Kruijf, P.; Hamidjaja, R.A.; Van Hoek, A.H.A.M.; De Roda Husman, A.M.; Schets, F.M. Prevalence and characteristics of ESBL-producing E. coli in Dutch recreational waters influenced by wastewater treatment plants. Vet. Microbiol. 2014, 171, 448-459. [CrossRef]

11. Sabri, N.A.; Schmitt, H.; Van der Zaan, B.; Gerritsen, H.W.; Zuidema, T.; Rijnaarts, H.H.M.; Langenhoff, A.A.M. Prevalence of antibiotics and antibiotic resistance genes in a wastewater effluent-receiving river in the Netherlands. J. Environ. Chem. Eng. 2018. [CrossRef]

12. Manaia, C.M.; Rocha, J.; Scaccia, N.; Marano, R.; Radu, E.; Biancullo, F.; Cerqueira, F.; Fortunato, G.; Iakovides, I.C.; Zammit, I.; et al. Antibiotic resistance in wastewater treatment plants: Tackling the black box. Environ. Int. 2018, 115, 312-324. [CrossRef] [PubMed]

13. Wose Kinge, C.N.; Ateba, C.N.; Kawadza, D.T. Antibiotic resistance profiles of Escherichia coli isolated from different water sources in the Mmabatho locality, Northwest Province, South Africa. S. Afr. J. Sci. 2010, 106. [CrossRef]

14. Schauss, T.; Glaeser, S.P.; Gütschow, A.; Dott, W.; Kämpfer, P. Improved Detection of Extended Spectrum Beta-Lactamase (ESBL)Producing Escherichia coli in Input and Output Samples of German Biogas Plants by a Selective Pre-Enrichment Procedure. PLoS ONE 2015, 10, e0119791. [CrossRef]

15. Opintan, J.A.; Newman, M.J.; Arhin, R.E.; Donkor, E.S.; Gyansa-Lutterodt, M.; Mills-Pappoe, W. Laboratory-based nationwide surveillance of antimicrobial resistance in Ghana. Infect. Drug Resist. 2015, 8, 379-389. [CrossRef]

16. Obeng-Nkrumah, N.; Twum-Danso, K.; Krogfelt, K.A.; Newman, M.J. High levels of extended-spectrum beta-lactamases in a major teaching hospital in Ghana: The need for regular monitoring and evaluation of antibiotic resistance. Am. J. Trop. Med. Hyg. 2013, 89, 960-964. [CrossRef] [PubMed]

17. Agyepong, N.; Govinden, U.; Owusu-Ofori, A.; Amoako, D.G.; Allam, M.; Janice, J.; Pedersen, T.; Sundsfjord, A.; Essack, S. Genomic characterization of multidrug-resistant ESBL-producing Klebsiella pneumoniae isolated from a Ghanaian teaching hospital. Int. J. Infect. Dis. 2019, 85, 117-123. [CrossRef] [PubMed]

18. Anastasi, E.M.; Matthews, B.; Stratton, H.M.; Katouli, M. Pathogenic Escherichia coli found in sewage treatment plants and environmental waters. Appl. Environ. Microbiol. 2012, 78, 5536-5541. [CrossRef] [PubMed]

19. Korzeniewska, E.; Korzeniewska, A.; Harnisz, M. Antibiotic resistant Escherichia coli in hospital and municipal sewage and their emission to the environment. Ecotoxicol. Environ. Saf. 2013, 91, 96-102. [CrossRef]

20. Pan, M.; Chu, L.M. Transfer of antibiotics from wastewater or animal manure to soil and edible crops. Environ. Pollut. 2017, 231, 829-836. [CrossRef]

21. Adelowo, O.O.; Caucci, S.; Banjo, O.A.; Nnanna, O.C.; Awotipe, E.O.; Peters, F.B.; Fagade, O.E.; Berendonk, T.U. Extended Spectrum Beta-Lactamase (ESBL)-producing bacteria isolated from hospital wastewaters, rivers and aquaculture sources in Nigeria. Environ. Sci. Pollut. Res. 2018, 25, 2744-2755. [CrossRef] [PubMed]

22. Aworh, M.K.; Kwaga, J.; Okolocha, E.; Harden, L.; Hull, D.; Hendriksen, R.S.; Thakur, S. Extended-spectrum ß-lactamaseproducing Escherichia coli among humans, chickens and poultry environments in Abuja, Nigeria. One Health Outlook 2020, 2, 8. [CrossRef]

23. Wang, Y.; Moe, C.L.; Teunis, P.F.M. Children Are Exposed to Fecal Contamination via Multiple Interconnected Pathways: A Network Model for Exposure Assessment. Risk Anal. 2018, 38, 2478-2496. [CrossRef]

24. WHO. Guidelines for Drinking-Water Quality, 4th ed.; World Health Organization: Geneva, Switzerland, 2017; Volume 4, ISBN 97892-4-154995-0. Available online: http:/ / www.who.int/water_sanitation_health/publications/drinking-water-quality-guidelines4-including-1st-addendum/en/ (accessed on 20 June 2021).

25. Matheu, J.; Awa, A.-K.; Andremont, A. The ESBL Tricycle AMR Surveillance Project: A Simple, One Health Approach to Global Surveillance I AMR Control. Available online: http: / / resistancecontrol.info/2017/the-esbl-tricycle-amr-surveillance-project-asimple-one-health-approach-to-global-surveillance/ (accessed on 22 March 2021).

26. Johnson, A.; Ginn, O.; Bivins, A.; Rocha-Melogno, L.; Tripathi, S.N.; Brown, J. Extended-spectrum beta-lactamase (ESBL)-positive Escherichia coli presence in urban aquatic environments in Kanpur, India. J. Water Health 2020. [CrossRef]

27. Thanner, S.; Drissner, D.; Walsh, F. Antimicrobial Resistance in Agriculture. MBio 2016, 7, e02227-15. [CrossRef] [PubMed] 
28. WHO Integrated Global Surveillance on ESBL-Producing E. coli Using a "One Health" Approach. Available online: https://www. who.int/publications/i/item/who-integrated-global-surveillance-on-esbl-producing-e.-coli-using-a-one-health-approach (accessed on 29 March 2021).

29. Fund, F.; Davies, D.S.; Fund, F.; Organisation, A.; Organisation, W.; Health, A. The Fourth Improve Global Commandment Surveillance of Drug Resistance and Antimicrobial Consumption in Humans and Animals. Available online: extension://bfdogplmndidlpjfhoijckpakkdjkkil/pdf/viewer.html?file=https $\% 3 \mathrm{~A} \% 2 \mathrm{~F} \% 2 \mathrm{~F}$ carb-x.org $\% 2 \mathrm{Fwp}$-content $\%$ 2Fuploads\%2F2018\%2F12\%2FSfAM-Ten-Commandments-.pdf (accessed on 20 June 2021).

30. Ghana Statistical Services. Available online: https://www.statsghana.gov.gh/regionalpopulation.php?population=MTQ1 MTUyODEyMC43MDc1\&\&Western\&regid=7 (accessed on 11 March 2021).

31. Council of Scientific \& Industrial Research. Water Resources of Ghana, 1st ed.; Philip Gyau-Boakye \& Kwabena Kankam-Yeboah; CSIR-INSTI: Accra, Ghana, 2016; ISBN 978-9988-2-3380-2-3380-8.

32. UWP Experts. Accra, Ghana Metro Area Population 1950-2021 I MacroTrends. Available online: https://www.macrotrends.net/ cities/21107/accra/population (accessed on 11 March 2021).

33. Sagoe, G.; Danquah, F.S.; Amofa-Sarkodie, E.S.; Appiah-Effah, E.; Ekumah, E.; Mensah, E.K.; Karikari, K.S. GIS-aided optimisation of faecal sludge management in developing countries: The case of the Greater Accra Metropolitan Area, Ghana. Heliyon 2019, 5. [CrossRef]

34. Bpd, K.C. Quick Stakeholder/Context Analysis of Public Toilets in Kumasi, Ghana: Initial Recommendations for WSUP; Unpublished Report; Building Partnership for Development in Water and Sanitation (BPD): London, UK, 2010.

35. WSUP Situation Analysis of the Urban Sanitation Sector in Ghana-Water \& Sanitation for the Urban Poor. Available online: https:/ / www.wsup.com/insights/situation-analysis-of-the-urban-sanitation-sector-in-ghana/ (accessed on 1 March 2021).

36. Agyemang, F.S.K.; Amedzro, K.K.; Silva, E. The emergence of city-regions and their implications for contemporary spatial governance: Evidence from Ghana. Cities 2017, 71, 70-79. [CrossRef]

37. APHA. Standard Methods for the Examination of Water and Wastewater, 22nd ed.; Rice, E.W., Baird, R.B., Eaton, A.D., Clesceri, L.S., Eds.; American Public Health Association (APHA), American Water Works Association (AWWA) and Water Environment Federati: Washington, DC, USA, 2012.

38. ISO 19458:2005, IDT Water Quality—Sampling for Microbiological Analysis. CP 401-1214 Vernier, Geneva, Switzerland. Available online: https:/ / www.iso.org/standard/33845.html (accessed on 20 June 2021).

39. CLSI. Performance Standards for Antimicrobial Susceptibility Testing, 27th ed.; CLSI Supplement M100; 547 Clinical and Laboratory Standards Institute: Wayne, PA, USA, 2017; ISBN 1-56238-1-56238-805-3. Available online: https:/ /www.iso.org (accessed on 20 June 2021).

40. ISO 8199:2005 Water Quality-General Guidance on the Enumeration of micro-Organisms by Culture. Case Postale 56 CH-1211 Geneva 20, Switzerland. Available online: https:/ / www.iso.org/standard/37011.html (accessed on 20 June 2021).

41. WHO. Guidelines for the Safe Use of Wastewater, Excreta and Greywater-Volume 4; World Health Organization: Geneva, Switzerland ISBN 1-56238-805-3. Available online: http:/ / www.who.int/water_sanitation_health/publications/gsuweg4/en/ (accessed on 20 June 2021).

42. EPA Sector Specific Effluent Quality Guidelines for Discharges; Ghana Environmental Protection Agency: Accra, Ghana, 2000.

43. Nzima, B.; Adegoke, A.A.; Ofon, U.A.; Al-Dahmoshi, H.O.M.; Saki, M.; Ndubuisi-Nnaji, U.U.; Inyang, C.U. Resistotyping and extended-spectrum beta-lactamase genes among Escherichia coli from wastewater treatment plants and recipient surface water for reuse in South Africa. New Microbes New Infect. 2020, 38, 100803. [CrossRef]

44. Amaya, E.; Reyes, D.; Paniagua, M.; Calderón, S.; Rashid, M.U.; Colque, P.; Kühn, I.; Möllby, R.; Weintraub, A.; Nord, C.E. Antibiotic resistance patterns of Escherichia coli isolates from different aquatic environmental sources in León, Nicaragua. Clin. Microbiol. Infect. 2012, 18, E347-E354. [CrossRef]

45. Berendes, D.M.; de Mondesert, L.; Kirby, A.E.; Yakubu, H.; Lady, A.; Michiel, J.; Raj, S.; Robb, K.; Wang, Y.; Doe, B.; et al. Variation in E. coli concentrations in open drains across neighborhoods in Accra, Ghana: The influence of onsite sanitation coverage and interconnectedness of urban environments. Int. J. Hyg. Environ. Health 2020, 224, 113433. [CrossRef] [PubMed]

46. Gyan, K. Planning and Provision of Public Infrastructure: A Case Study of Drainage Canals in Tema, Ghana; Iowa State University: Ames, Iowa, 2019; Available online: https:/ / lib.dr.iastate.edu/creativecomponents (accessed on 20 June 2021).

47. Gretsch, S.R.; Ampofo, J.A.; Baker, K.K.; Clennon, J.; Null, C.A.; Peprah, D.; Reese, H.; Robb, K.; Teunis, P.; Wellington, N.; et al. Quantification of exposure to fecal contamination in open drains in four neighborhoods in Accra, Ghana. J. Water Health 2016. [CrossRef]

48. van den Bunt, G.; van Pelt, W.; Hidalgo, L.; Scharringa, J.; de Greeff, S.C.; Schürch, A.C.; Mughini-Gras, L.; Bonten, M.J.M.; Fluit, A.C. Prevalence, risk factors and genetic characterisation of extended-spectrum beta-lactamase and carbapenemase-producing Enterobacteriaceae (ESBL-E and CPE): A community-based cross-sectional study, the Netherlands, 2014 to 2016. Euro Surveill. Bull. Eur. sur les Mal. Transm. Eur. Commun. Dis. Bull. 2019, 24. [CrossRef] [PubMed]

49. Riccio, M.E.; Verschuuren, T.; Conzelmann, N.; Martak, D.; Meunier, A.; Salamanca, E.; Delgado, M.; Guther, J.; Peter, S.; Paganini, J.; et al. Household acquisition and transmission of extended-spectrum $\beta$-lactamase (ESBL)-producing Enterobacteriaceae after hospital discharge of ESBL-positive index patients. Clin. Microbiol. Infect. Off. Publ. Eur. Soc. Clin. Microbiol. Infect. Dis. 2021. [CrossRef] 
50. Maataoui, N.; Langendorf, C.; Berthe, F.; Bayjanov, J.R.; van Schaik, W.; Isanaka, S.; Grais, R.F.; Clermont, O.; Andremont, A.; Armand-Lefèvre, L.; et al. Increased risk of acquisition and transmission of ESBL-producing Enterobacteriaceae in malnourished children exposed to amoxicillin. J. Antimicrob. Chemother. 2020, 75, 709-717. [CrossRef] [PubMed]

51. Hocquet, D.; Muller, A.; Bertrand, X. What happens in hospitals does not stay in hospitals: Antibiotic-resistant bacteria in hospital wastewater systems. J. Hosp. Infect. 2016, 93, 395-402. [CrossRef] [PubMed]

52. Diallo, A.A.; Brugère, H.; Kérourédan, M.; Dupouy, V.; Toutain, P.-L.; Bousquet-Mélou, A.; Oswald, E.; Bibbal, D. Persistence and prevalence of pathogenic and extended-spectrum beta-lactamase-producing Escherichia coli in municipal wastewater treatment plant receiving slaughterhouse wastewater. Water Res. 2013, 47, 4719-4729. [CrossRef] [PubMed]

53. Vivant, A.L.; Boutin, C.; Prost-Boucle, S.; Papias, S.; Hartmann, A.; Depret, G.; Ziebal, C.; Le Roux, S.; Pourcher, A.M. Free water surface constructed wetlands limit the dissemination of extended-spectrum beta-lactamase producing Escherichia coli in the natural environment. Water Res. 2016, 104, 178-188. [CrossRef] [PubMed]

54. Robinson, T.P.; Bu, D.P.; Carrique-Mas, J.; Fèvre, E.M.; Gilbert, M.; Grace, D.; Hay, S.I.; Jiwakanon, J.; Kakkar, M.; Kariuki, S.; et al. Antibiotic resistance is the quintessential One Health issue. Trans. R. Soc. Trop. Med. Hyg. 2016, 110, 377-380. [CrossRef]

55. U.S. Environmental Protection Agency. National Recommended Water Quality Criteria-Aquatic Life Criteria Table. Office of Water (4301T) 1200 Pennsylvania Avenue, N.W. Washington, DC, USA, 20460. Available online: https:/ /www.epa.gov/wqc/ national-recommended-water-quality-criteria-aquatic-life-criteria-table (accessed on 20 June 2021).

56. Stocker, M.D.; Penrose, M.; Pachepsky, Y.A. Spatial Patterns of Escherichia coli Concentrations in Sediment before and after High-Flow Events in a First-Order Creek. J. Environ. Qual. 2018, 47, 958-966. [CrossRef] [PubMed]

57. Pachepsky, Y.A.; Shelton, D.R. Escherichia Coli and Fecal Coliforms in Freshwater and Estuarine Sediments. Crit. Rev. Environ. Sci. Technol. 2011, 41, 1067-1110. [CrossRef]

58. Zhang, S.; Guo, L.; Yang, K.; Zhang, Y.; Ye, C.; Chen, S.; Yu, X.; Huang, W.E.; Cui, L. Induction of Escherichia coli Into a VBNC State by Continuous-Flow UVC and Subsequent Changes in Metabolic Activity at the Single-Cell Level. Front. Microbiol. 2018, 9 , 2243. [CrossRef]

59. Hodgson, I. Performance of the Akosombo Waste Stabilization Ponds In Ghana. Ghana J. Sci. 2008, 47, 35-44. [CrossRef]

60. Diwan, V.; Hanna, N.; Purohit, M.; Chandran, S.; Riggi, E.; Parashar, V.; Tamhankar, A.J.; Stålsby Lundborg, C. Seasonal variations in water-quality, antibiotic residues, resistant bacteria and antibiotic resistance genes of Escherichia coli isolates from water and sediments of the Kshipra River in Central India. Int. J. Environ. Res. Public Health 2018, 15, 1281. [CrossRef] [PubMed]

61. Ciebin, B.W.; Brodsky, M.H.; Eddington, R.; Horsnell, G.; Choney, A.; Palmateer, G.; Ley, A.; Joshi, R.; Shears, G. Comparative evaluation of modified $\mathrm{m}-\mathrm{FC}$ and $\mathrm{m}$-TEC media for membrane filter enumeration of Escherichia coli in water. Appl. Environ. Microbiol. 1995, 61, 3940-3942. [CrossRef] [PubMed]

62. Fricker, C.R.; Warden, P.S.; Eldred, B.J. Understanding the cause of false negative $\beta$-d-glucuronidase reactions in culture media containing fermentable carbohydrate. Lett. Appl. Microbiol. 2010, 50, 547-551. [CrossRef]

63. Eurofins EPTIS-PT Scheme for Water Microbiology (EPTIS-ID 134754). Available online: https://www.eptis.bam.de/eptis/ WebSearch/view/134754 (accessed on 18 March 2021).

64. Von Elm, E.; Altman, D.G.; Egger, M.; Pocock, S.J.; Gøtzsche, P.C.; Vandenbroucke, J.P. The Strengthening the Reporting of Observational Studies in Epidemiology (STROBE) Statement: Guidelines for reporting observational studies*. Bull. World Health Organ. 2007, 85, 867-872. [CrossRef] [PubMed] 